IZA DP No. 6736

Can Mistargeting Destroy Social Capital and Stimulate Crime? Evidence from a Cash Transfer Program in Indonesia

Lisa Cameron

Manisha Shah

July 2012 


\title{
Can Mistargeting Destroy Social Capital and Stimulate Crime? Evidence from a Cash Transfer Program in Indonesia
}

\author{
Lisa Cameron \\ Monash University \\ and IZA \\ Manisha Shah \\ University of California-Irvine, \\ NBER and IZA
}

Discussion Paper No. 6736

July 2012

IZA

P.O. Box 7240

53072 Bonn

Germany

Phone: +49-228-3894-0

Fax: +49-228-3894-180

E-mail: iza@iza.org

Any opinions expressed here are those of the author(s) and not those of IZA. Research published in this series may include views on policy, but the institute itself takes no institutional policy positions.

The Institute for the Study of Labor (IZA) in Bonn is a local and virtual international research center and a place of communication between science, politics and business. IZA is an independent nonprofit organization supported by Deutsche Post Foundation. The center is associated with the University of Bonn and offers a stimulating research environment through its international network, workshops and conferences, data service, project support, research visits and doctoral program. IZA engages in (i) original and internationally competitive research in all fields of labor economics, (ii) development of policy concepts, and (iii) dissemination of research results and concepts to the interested public.

IZA Discussion Papers often represent preliminary work and are circulated to encourage discussion. Citation of such a paper should account for its provisional character. A revised version may be available directly from the author. 
IZA Discussion Paper No. 6736

July 2012

\section{ABSTRACT}

\section{Can Mistargeting Destroy Social Capital and Stimulate Crime? Evidence from a Cash Transfer Program in Indonesia}

Cash transfer programs can provide important financial support for poor households in developing countries and are becoming increasingly common. However the potential for mistargeting of program funds is high. This paper focuses on the social consequences arising from misallocation of resources in close knit communities. We find that the mistargeting of a cash transfer program in Indonesia is significantly associated with increases in crime and declines in social capital within communities. Hence poorly administered transfer programs have a potentially large negative downside that extends beyond the pure financial costs that have been the focus of the literature to date.

JEL Classification: $\quad$ O12, O15, I38

Keywords: cash transfer programs, crime, mistargeting, social capital

Corresponding author:

Lisa Cameron

Department of Econometrics

Monash University

Clayton 3800 Victoria

Australia

E-mail: lisa.cameron@monash.edu 


\section{Introduction}

Developing countries are increasingly using cash transfers as a means of providing financial support to poorer households. These countries however rarely have the detailed, verifiable and legally enforceable data bases that form part of the tax and welfare systems in industrialized nations. As a result, accurate targeting of such transfers in developing nations is very difficult.

Several recent papers have examined the problem of targeting (see for example Coady et al. (2004)). The focus of these papers has been the distributional consequences of undercoverage of eligible recipients (errors of exclusion) and leakage of funds to non-eligible households (errors of inclusion). The downside of poor implementation of such programs however extends beyond financial losses to the potential destruction of trust and social capital which can, amongst other things, increase the prevalence of anti-social behavior like crime (Putnam, 2000). The general media and sociological literature has discussed the possible drawbacks that can accompany the formalization of social security (for example, see Berger and Neuhaus (1996)) but there has been little attention paid to the social consequences of mistargeting in the economics literature. A recent notable exception is Alatas et al. (2011) which uses a randomized controlled trial to show that while statistical targeting methods such as proxy means testing can do a better job of identifying households with low per capita expenditure than community rankings, community rankings result in higher community satisfaction. ${ }^{1}$

We explore the impact of Bantuan Langsung Tunai (BLT) which was a large scale, nationwide program in Indonesia which reportedly caused a lot of social disharmony. The program used a variant of proxy means testing to target eligible households. The aim of this paper is to use nationally representative data to verify the anecdotal reports of social unrest and to isolate the mechanisms-we find that it is leakage of funds to better-off households, not undercoverage of poorer households that was to blame. We show that when people are unhappy with targeting methods the social costs can be quite large, suggesting that community satisfaction is a meter that should perhaps be taken into account when choosing between targeting methods.

The BLT program aimed to compensate poor households for a sudden and large increase in fuel costs that resulted from the removal of fuel subsidies. Costing approximately one billion U.S. dollars, this is one of the largest cash transfer programs in the developing world. ${ }^{2}$ The poor targeting

\footnotetext{
${ }^{1}$ Another exception is Gugerty and Kremer (2002) who find that outside funding of community organizations reduces the involvement of the poor.

${ }^{2}$ World Bank (2006), p182. BLT translates as 'Direct Cash Assistance'. We examine the 2005 BLT program. The program has since been implemented again in 2008-2009 with better targeting and less social unrest (see Satriana
} 
that resulted from its rapid implementation is well-documented (Hastuti et al., 2006a,b). Close to half a billion U.S. dollars made its way to ineligible households. The social unrest that resulted was widely reported in the media and extended from protests across the nation to acts as extreme as the burning down and stoning of village heads' offices (Widjaja, 2009). We hypothesize that the poor implementation of the program that saw many eligible households miss out on the payments and many ineligible households receive them, reduced the level of trust within the community, had a deleterious effect on social capital, and led to an increase in anti-social, and in some cases criminal behavior.

We test the impact on crime directly and find that as a result of poor targeting, crime increased by approximately 0.13 percentage points, or $5.8 \%$ (which means approximately 70,000 more households were victims of crime than if the program had been accurately targeted). ${ }^{3}$ Our results withstand a range of robustness tests that examine possible alternative interpretations such as reverse causality and omitted third factors.

Using a smaller, supplementary data set with more detailed information on social capital than in the nationally representative data, we establish that social capital - as measured by people's participation in community groups - was significantly adversely affected by the poor targeting. This is in line with qualitative reports from surveys of village heads that the BLT program made it harder to get households to work together for the betterment of the community (Hastuti et al., 2006a). Finally, to close the causal chain and in support of our original hypothesis, we show that villages that experienced decreases in community participation were more likely to report declines in perceptions of safety.

We find that some types of mistargeting are more harmful than others. Leakage (the share of ineligible households who received the funds) is a strong determinant of both increases in crime and decreases in social capital. In contrast, undercoverage (the share of eligible households who did not receive the payment) is much more weakly associated with crime and is not a predictor of changes in social capital.

The remainder of the paper is structured as follows. Section 2 discusses the conceptual framework. Section 3 describes the BLT program as it was implemented in October 2005. The data sources are described in Section 4, and the empirical methodology in Section 5. Section 6 presents the main results, Section 7 presents various robustness tests, and we explore the mechanisms by $(2009))$.

${ }^{3}$ These figures are calculated from household level regressions with district fixed effects and controls for a range of household and village characteristics, including pre-program crime. See Table 5, Column 4. 
which the program increased crime in Section 8. Section 9 concludes.

\section{Conceptual Framework}

The aim of this paper is to identify whether, and to what extent, the introduction of the BLT program increased crime. BLT could lead to increases in crime in the following ways. Most obviously, BLT mistargeting caused arbitrary changes to the income distribution and may have increased inequality. Previous papers have illustrated that increased inequality can lead to increased crime (Bourguignon, 1999; Fajnzylber et al., 2002). For example, Demombynes and Özler (2005) using data from South Africa find a positive relationship between both mean household expenditure and inequality and property crime.

Alternatively or additionally, BLT mistargeting may have invoked a sense of injustice which resulted in a deterioration in trust (social capital) between villagers. ${ }^{4}$ This feeling of injustice may have arisen from the arbitrary nature of the allocation of the funds or may have stemmed directly from villagers observing elite capture of the program (village heads allocating the program to their friends for example).

There is ample support in the sociology and criminology literature that declines in social capital are associated with increases in crime. For example, Putnam (2000) argues that the presence or absence of networks of generalized trust and reciprocity within communities are an important determinant of a community's resilience or susceptibility to crime. Similarly, Bursik and Grasmick (1993) view weak social controls (as reflected in low social capital) as harming the ability of groups to organize and protect themselves which induces mistrust and suspicion and leads to predatory crime. Related theories predict where there is not a strong moral order, and people behave egoistically and are willing to exploit others, social trust declines and crime flourishes (Rosenfeld and Messner, 1998). These theories suggest that the crime that results from a decline in social capital is not necessarily targeted at those who caused the decline by acting "badly." For example, in the current context, those who misappropriate BLT funds might not necessarily be the target, but rather, the theories predict general increases in crime when social capital declines. ${ }^{5}$

Results from a survey conducted by the authors across the Indonesian province of East Java

\footnotetext{
${ }^{4}$ Social capital can be broadly defined as the set of rules, norms, obligations, reciprocity, and trust embedded in social relations, social structures, and societies' institutional arrangements that enable members to achieve their individual and community objectives (Coleman, 1990).

${ }^{5}$ The above mechanisms can be incorporated in the classical Beckerian model where crime is a rational choice between legitimate and illegitimate sources of income; and crime, if detected, is punished. In close-knit rural villages "punishment" often takes the form of social isolation. Decreases in a community's stock of social capital reduces the effectiveness of this mechanism, and as in the standard model, less effective punishment results in increased crime.
} 
indicate the level of discontent with the program and the likelihood that social capital was adversely affected. Of the 160 community leaders surveyed, $40 \%$ said that the BLT caused problems in their village. ${ }^{6}$ Twenty-nine percent of households said it caused anger towards community and village heads, $8 \%$ said it caused anger towards the government, and $8 \%$ said it caused anger towards BLT recipients.

In Section 8 below, we examine the mechanism via which mistargeting led to increases in crime and explore the extent to which increased inequality and declines in social capital played a role.

\section{The BLT Program}

The Indonesian government reduced fuel subsidies on 1 October 2005. The fuel subsidies were expensive, caused the government budget to fluctuate with world oil prices and largely benefited the well-off because they consume the most fuel. However, the price of kerosene, which many poor households use for cooking and lighting, rose by 185.7 percent. $^{7}$ To compensate the poor for these price rises a compensation program, Bantuan Langsung Tunai (BLT) was introduced. All households with a monthly per capita expenditure of less than Rp175,000 (US\$17) were to receive Rp100,000 per month for six months. ${ }^{8}$ This amounted to $22 \%$ of monthly household expenditure for these households on average and was paid in two three month lump sums. Approximately 18.6 million households (or approximately one third of all Indonesian households) were to receive the payment (World Bank, 2006).

From the outset the program was beset with problems which stemmed from the short time period for program development and implementation, approximately three months. The greatest hurdle to be overcome was the targeting of the nation's poor. No national data base of household incomes or expenditures exists in Indonesia ${ }^{9}$ which is the case for most developing countries.

To deal with this lack of data, a proxy-means testing approach was developed. The procedure consists of a number of steps. First, data from the detailed annual national socio-economic survey (Susenas) for the years 2002, 2003 and 2004 was combined and used to identify 14 variables that

\footnotetext{
${ }^{6}$ In response to the open ended question "In your opinion, what is the biggest problem in this village?" Nine percent of the over 1500 households surveyed volunteered BLT as constituting the main problem in their community.

${ }^{7}$ Gasoline prices increased by $87.5 \%$ and diesel increased $104.8 \%$ (Widjaja, 2009).

${ }^{8}$ This is slightly higher than the 2004 official poverty line of Rp110,000/capita/month. Many households in Indonesia are clustered around the poverty line. For this reason a cut-off point that included some of the 'near poor' was chosen. No geographic targeting was used.

${ }^{9}$ Past safety net programs used the National Family Planning Agency's data base (Badan Koordinasi Keluarga Berencana Nasional, BKKBN) which defines households as being 'pre-prosperous' on the basis of four questions on whether the household members eat three times a day, have a change of clothes, live in a house with a dirt floor and are able to observe their religious duties. This approach had met with mixed success (Pritchett et al., 2002). See also Alatas et al. (2011) for a discussion of targeting methods in the context of Indonesia.
} 
together had the greatest ability to predict household expenditure. This was done by estimating logistic regressions for each of the 377 districts (kabupaten/kota) in Indonesia. The list of these variables is presented in the appendix in Table 11. This process generated weights which would later be used to calculate a value for the poverty index for each household. ${ }^{10} \mathrm{~A}$ questionnaire was then constructed (Socio-economic Data Collection on the Population $2005=$ Pendataan Sosial Ekonomi Penduduk 2005: PSE05) to collect information on these variables from households.

Village heads in each of Indonesia's almost 70,000 villages were asked to provide a list of households which they considered to be poor. Enumerators from the Indonesian Statistical Agency (BPS) then went to the villages and used the new questionnaire to survey these poor households. While in the village the enumerator was also supposed to scout around and see whether s/he could identify any other poor households which would then be surveyed. In practice this often did not happen. ${ }^{11}$ Enumerators also often lived in the local area and claimed to know who was poor without further investigation. Hastuti et al. (2006a) reports that $48 \%$ of households stated that the BPS enumerator did not ask them the full range of questions. They also found that some enumerators included people living close to them in the survey regardless of the households' standard of living.

Once the data had been collected it was transferred to the central statistical office in Jakarta where the weights from the previous calculations were used to give each household a score. Households with a score above a certain cut-off point were deemed to be poor and so were to receive the BLT payment while those with lower scores were deemed to be too well-off to be eligible. The data was then sent to the Indonesian Postal Service for the production of compensation cards. These cards were then distributed to the sub-district statistical office which disbursed them either directly or through community leaders. The card had to be shown at the post office for receipt of benefits.

Distributing transfers on the basis of estimates of household expenditure undoubtedly led to substantial targeting error. Table 1 presents targeting statistics by quintiles of the per capita expenditure distribution and also according to the BLT criteria. The table is generated from the 2006 Susenas household survey data which is the main data source for this paper and which is discussed in detail below. The table shows that $43 \%$ of BLT recipients reported having per capita expenditures above the cut-off of Rp175,000 per month and that approximately $46.5 \%$ of these 'poor' households did not receive the payment. In terms of quintiles of the distribution, higher

\footnotetext{
${ }^{10}$ Coady et al. (2004) provides a general discussion of proxy-means methodology. BPS (2005) gives a description of the methodology as it was followed in Indonesia.

${ }^{11}$ The deadlines faced by enumerators simply did not provide enough time for this task to be carried out. The entire enumeration was scheduled to be undertaken between August 15 and September 15, 2005.
} 
percentages of those in the lower quintiles received the payment. ${ }^{12}$

Unhappiness with the targeting method caused severe social unrest. Table 2 from Widjaja (2009) shows the incidence of protests in response to the BLT. ${ }^{13}$ There were protests in $35 \%$ of the 566 villages surveyed. Respondents were asked about the cause of the unrest and $90 \%$ responded that the protests were caused by the flawed targeting method. ${ }^{14}$ Press reports cite instances where village and community leaders were the targets of violence and threats. There were many reports of village heads resigning and cases of village and sub-village heads offices and houses being burnt down and destroyed. ${ }^{15}$ Such violence was by no means isolated. In one of 10 villages studied in Hastuti et al. (2006a) the village office was stoned. This same study also reports that in several areas, the damage to socio-political order of the local community was considered bigger than the advantage that was received by the poor. Further, in focus group sessions community leaders voiced the concern that the program was counter-productive to other programs that relied on community empowerment. Almost all village officials said that they were negatively affected by the program and in several villages it was reported that it became more difficult to request residents to engage in mutual assistance activities and village tax levies were negatively affected. ${ }^{16}$

Note though that the use of proxy-means as a targeting mechanism is not uncommon. Coady et al. (2004) provide a comparison of 49 targeted cash programs in low or medium income countries, including several that use proxy-means testing. They conclude that it is one of the more accurate targeting mechanisms. Indeed the BLT targeting performance is not seriously worse than that in many programs that have not met with unrest. Table 3 presents a comparison of targeting performance of a number of cash transfer programs. The targeting performance of the BLT program is considerably worse than programs in Brazil, the Dominican Republic, Chile and Nicaragua but a greater proportion of the funds reached the poorest $20 \%$ of households than in Mexico's Progresa program which is widely considered a role model for cash transfer programs and met with no social

\footnotetext{
${ }^{12}$ The BLT mistargeting rate is very similar to that which results from the same targeting method in Alatas et al. (2011) targeting experiment in Indonesia. They find that $30 \%$ of households were mistargeted. That is, either eligible households did not receive the payment or ineligible households did. In our sample, $26 \%$ of households were mistargeted.

${ }^{13}$ Calculated using data from the 2006 Susenas panel which is conducted by the Indonesian Statistical Agency.

${ }^{14}$ Other responses were lack of clarity about the distribution schedule (1\%); lack of clarity about the distribution location $(2 \%)$; recipients not receiving the full sum $(2 \%)$; lack of coordination between agencies in the distribution chain $(4 \%)$; and complicated processes $(1 \%)$.

${ }^{15}$ In sub-district Cibeber in Cianjur, all village heads planned to resign if supplementary registrations were not approved because they feared for their safety (Hastuti et al., 2006a).

${ }^{16}$ Hastuti et al. (2006a) conducted in-depth interviews with 93 recipient households, 30 non-recipient households and a number of key informants at various levels of government. In addition, focus group discussions were conducted with kabupaten/kota representatives, village representatives and with household recipients.
} 
unrest as far as we know. Hence, mistargeting may not of itself have led to social unrest. A further likely factor was the poor socialization of the program. That is, the aim of the program and who it was intended to aid was not well communicated to the population. There were no enforcement mechanisms in place, such as auditing of sub-samples of households to ensure they had been correctly categorized. Also, initially in many regions there was no formal mechanism via which households could appeal or voice complaints (see Hastuti et al. (2006a) for details).

The speed of implementation was a further contributing factor to these weaknesses in implementation. BLT was implemented simultaneously with a reduction in fuel subsidies. In contrast, Progresa accompanied a gradual elimination of food subsidies that began several years prior to its introduction and which was completed two years thereafter. BLT was also implemented simultaneously across the entire nation while Progresa was piloted prior to implementation and phased in gradually, initially to only a small number of poor, rural communities in 1997, expanding to include urban areas of up to a million people only in 2001 (Parker, 2003). Hence, the results presented below should be interpreted as a cautionary tale of how things can go wrong in a poorly targeted and particularly poorly implemented program.

\section{Data}

This paper draws on two main sources of data. The first source is the 2006 Indonesian SocioEconomic Census (Survei Sosial Ekonomi Nasional or Susenas). These data cover a random sample of 277,202 households and over 1.1 million individuals (about 1 in 200 of the Indonesian population) drawn from 15,612 villages across the Indonesian archipelago. The Susenas is conducted annually and collects information on a large range of demographic and economic variables. The 2006 Susenas was conducted in July 2006. In addition to the normal range of questions, in 2006 households were asked whether they received BLT and if so, in which month they first received it. This enables us to identify recipient households. All individuals in the household were also asked whether they were a victim of crime in the last year, to which they answered yes or no.

The second source of data is the Indonesian Village Census (Potensi Desa, PODES). The PODES is conducted every three years and collects a wide range of information from every village in Indonesia. It provides information on whether there were cases of 11 categories of crime in the previous year. The categories of crime are theft, looting, pillaging, assault, arson, rape, misuse of drugs, illegal drugs, murder, the sale of children and other. ${ }^{17}$ They are also asked to designate the

\footnotetext{
${ }^{17}$ The PODES respondent is the village head and/or another village representative. We use all categories of crime
} 
type of crime that occurred most often. The PODES was conducted pre-BLT in April 2005.

Figure 1 shows the timing of the surveys and the program. Note that the dates of the Susenas and PODES surveys allow us to closely examine the period of time over which the BLT would have impacted upon crime.

Both the PODES crime data and Susenas crime data rely on self-reports from surveyed individuals. This type of data suffers less from the under-reporting biases evident in police crime statistics. Gibson and Bonggeun (2006) using the International Criminal Victimization Surveys of 140,000 respondents in 37 industrial, transition and developing countries compare crimes experienced by these respondents with those reported to the police. They find that rates reported to the police are significantly lower than actual rates reported in individual interviews. The Susenas is a household survey so every household in the survey was asked about their experience of crime, alleviating the underreporting problem as well as the concern of selection based on who chooses to report crimes to the police. ${ }^{18}$ A weakness of the Susenas crime measure, however, is that it does not disaggregate by type of crime. In addition, we know nothing from our data sources about who is committing the crimes.

Table 4 presents summary statistics of the crime variables. Of the households in our sample, $2.8 \%$ had a member who was a victim of crime in the year up to July 2006. Twenty-seven percent of villages sampled in the Susenas have at least one household sampled that was a victim of crime. ${ }^{19}$

Table 4 also presents summary statistics of our mistargeting measures. (Variable definitions are given in Table 12 in the appendix.) Our two main measures of mistargeting are leakage (error of inclusion) and undercoverage (error of exclusion). Leakage is defined as the proportion of noneligible households in the village that received the payment. Undercoverage is the proportion of eligible households in the village who missed out on receiving the payment. Eligible households in any village in the nation were to receive the transfer. The table shows that $87.8 \%$ of the villages in

so that the variable generated is consistent with the Susenas question on crime which does not specify types. The results are however robust to including only categories of crime that we expect to be most strongly affected by the BLT which are theft, looting, pillaging, violence and arson.

${ }^{18}$ The 2009 Susenas asks whether respondents have been a victim of crime, and if so, whether it was reported to the police. It shows that only $16 \%$ of crimes were reported to police. This figure is higher, but still surprisingly low, for serious violent crimes. For example, only $58 \%$ of murders are reported to police.

${ }^{19}$ The International Crime Victims Survey (ICVS), a household survey which compares levels of victimization across countries, shows that crime rates in Asia are significantly lower than crime rates in Latin American and Africa. The crime rates in our sample are lower than in the ICVS but the same order of magnitude. The ICVS reports that $5.0 \%$ of households had experienced a burglary in the previous 12 months; $5.6 \%$ personal theft; $0.6 \%$ robbery and $2.6 \%$ assault. The ICVS figures are likely to be higher because it only interviews in large urban centres. It was conducted in 1996-1997 and so may also be contaminated by the Asian Financial Crisis which started in mid-1997. See: http://www.unicri.it/documentation_centre/publications/icvs/data.php 
our sample had at least one household that reported receiving the BLT payment (BLT present=1). On average $20.6 \%$ of non-eligible households in a village received the BLT payment and $34.9 \%$ of eligible households missed out. Figures 2 and 3 show the distribution of the targeting variables. They show considerable variation across villages. In some villages there is no mistargeting but in a large proportion there is substantial mistargeting. In some villages all the eligible households missed out on the payment and/or all of the non-eligible received the payment. ${ }^{20}$

\section{Methodology}

The probability of household $i$ in village $v$ being a victim of crime is a function of both household and village characteristics. Household characteristics such as income, assets and demographic structure reflect the household's susceptibility to crime. The income and demographic structure of other households in the village captures both the propensity of village residents to engage in crime and the relative attractiveness of household $i$ as a victim. Institutional factors in the village, such as the presence of security posts and distance to police stations, also play a role.

We will thus model the probability of household $i$ in village $v$ in year $t$ being a victim of crime, crime $_{i v t}$, in the following way:

$$
\text { crime }_{i v t}=\alpha_{0}+\alpha_{1} X_{i v t}+\alpha_{2} Y_{v t}^{H H}+\alpha_{3} I N S T_{v t}+\alpha_{4} B L T_{v}+\eta_{v}+\epsilon_{i v t}
$$

where

$X_{i v t}$ are observed household level variables that affect the households susceptibility to crime;

$Y_{v t}^{H H}$ are observed village level variables that reflect the characteristics of other households in the village $v$;

$I N S T_{v t}$ are observed variables reflecting village $v$ 's institutions that affect crime levels;

$\eta_{v}$ is unobservable village characteristics that affect crime; and

$\epsilon_{i v t}$ is a random error term.

In addition to these standard variables we add a vector of variables, $\mathrm{BLT}_{v}$, which reflect the presence and targeting of BLT within the village.

A concern with estimating an equation like (1) is that it is possible there are unobservable variables that affect both crime and the implementation of BLT. One could imagine, for example, a village head who is administratively incompetent. The consequent disorganization may result in

\footnotetext{
${ }^{20}$ In villages with no eligible households, undercoverage is set to 0 . Similarly, in villages with no non-eligible households, leakage is set to 0 .
} 
crime being high and BLT being poorly administered but no causal relationship may exist between the two. The coefficient on the BLT variable will then be biased. However, if the unobserved variable is not time-varying (as is likely to be the case when examining a short time period like the one here of 15 months) then it can be differenced out. The estimating equation then becomes:

$$
\Delta \text { crime }_{i v t}=\alpha_{1} \Delta X_{i v t}+\alpha_{2} \Delta Y_{v t}^{H H}+\alpha_{3} \Delta I N S T_{v t}+\alpha_{4} B L T_{v}+e_{i v t}
$$

where $\Delta$ indicates a time difference and $e_{i v t}$ is the differenced random error term. That is, the examination of whether crime increased relatively more in villages where BLT was poorly targeted should yield unbiased estimates. ${ }^{21}$

Estimating equation (2) requires a panel of household data. The Susenas is a repeated crosssection with different individuals being surveyed each year so does not enable us to do this. ${ }^{22}$ Taking village averages of equation (2) yields:

$$
\Delta \text { Crime }_{v t}=\alpha_{1} \Delta X_{v t}+\alpha_{2} \Delta Y_{v t}^{H H}+\alpha_{3} \Delta I N S T_{v t}+\alpha_{4} B L T_{v}+u_{v t}
$$

where crime $_{v t}$ is the village crime rate and $X_{v t}$ is the village mean of household characteristics like income and assets. Although the Susenas is conducted yearly, prior to 2006, the most recent year in which the crime question was asked is 2000. Further, only a sub-sample of villages appears in any two years of the survey. Thus, estimating Equation (3) using two waves of the Susenas data would result in an $83 \%$ decrease in sample size and a very long time difference. The six year time difference, 2000 to 2006, is too long a period over which to examine the impact of a program that did not start until October 2005. Instead we use the PODES data to construct an indicator of whether or not there was crime in the village prior to the introduction of BLT. We use this as our baseline crime measure. How this is implemented will be explained in more detail below.

\section{Results}

We first present results from estimating the relationship between crime and BLT receipt in levels. These results establish that crime is correlated with various village and household characteristics in several expected ways. We then move on to discuss the relationship between crime and the BLT variables in differences.

\footnotetext{
${ }^{21}$ Note $B L T_{v}$ appears in levels here because the program only exists in one period and so the variables reflecting its presence and targeting equal zero in the previous period.

${ }^{22}$ The Susenas also samples from different villages each year. Thus we cannot estimate equation (1) on a panel of villages
} 


\subsection{Results in Levels}

Column 1 of Table 5 shows that richer households (those in the top decile of the national per capita expenditure distribution) are 0.5 percentage points (or 18\%) more likely to be a victim of crime. This is consistent with Anderson (2008) study of South Africa and results from richer households being more lucrative targets. Living in a village with more wealthy people (a greater proportion of households in the highest decile of the national per capita expenditure distribution) also increases one's probability of being a victim of crime, regardless of one's own living standards. ${ }^{23}$ Crime is also higher in villages with greater inequality, as measured by the Gini coefficient, consistent with the findings from Demombynes and Özler (2005) for South Africa.

Rural villages have no more or less crime than urban villages but the time it takes to get to a local center (kota kecamatan) is positively and significantly related to the crime rate. Being an hour farther away increases the probability of being a victim of crime by 0.24 percentage points (8.8\%). This may reflect distance from law enforcement authorities and is consistent with the findings of Fafchamps and Moser (2003) for Madagascar. We investigate the impact of law enforcement on crime in more detail below. Having fewer men in the village is also positively correlated with crime. Crime also increases with village population. Living in a village with an extra 1000 people increases the probability of being a victim of crime by 0.2 percentage points $(7.4 \%)$. The results in Column 1 thus indicate that our crime results are consistent with previous research in this area.

Column 2 in Table 5 shows the results from estimating equation 1. It includes an indicator variable (BLT present) that equals 1 if anyone in the sample from the village reported receiving the BLT. This variable is statistically significant at the .01 level and indicates that living in a village in which the BLT has been active increases the probability of being a victim of crime by 0.7 percentage points, or 23.6 percent. Note that this result is not being driven by these villages being poorer than others and so being more adversely affected by the fuel price increases. This can be seen by the coefficient on the proportion of village households that are "poor" (\% households eligible) where we define poor to correspond with eligibility for the BLT (that is, those households with per capita expenditure less than Rp175,000). ${ }^{24}$ This variable is not significant in column 2 and

\footnotetext{
${ }^{23}$ We also ran specifications that included controls for all deciles of the income distribution but only the top decile was significantly different from the others.

${ }^{24}$ Per capita expenditure is calculated as pre-BLT expenditure. That is, we subtract off the amount of BLT payment the household would have received from total expenditure and then divide through by the number of household members. We use the date at which the household first received BLT to calculate how many payments the household is likely to have received by the time of the survey. The results are however very similar to those which use actual per capita expenditure.
} 
is negatively correlated with crime in later specifications. In fact, our results suggest that richer villages experience more crime.

Column 2 also shows that mistargeting is significantly associated with crime levels. The variable leakage is statistically significant at the .01 level and indicates that for every additional $10 \%$ of nonpoor households that receive the payment the probability of being a victim of crime increases by 0.1 percentage points or 4.4 percent. In contrast, undercoverage is not statistically significant.

Column 2 also includes indicator variables at the household level that show whether the household was eligible and received the BLT (BLT-poor); whether the household was not eligible but received the BLT (BLT-non-poor); and whether the household was eligible but did not receive the BLT (No BLT-poor). Thus the omitted category is non-eligible households that did not receive the BLT. These household variables indicate that although there is more crime in villages where there is more leakage, those non-poor households that received the BLT payment are actually $16 \%$ less likely than other households to be a victim of crime. This is consistent with the BLT resulting in a general increase in crime in the village and these households' connections providing them with protection of some sort, as well as access to the payment for which they were ineligible. This thus suggests some degree of elite capture. We will return to this below.

The inclusion of the BLT variables does not affect the significance of the other variables described above such as inequality, size of village, income, and share of men.

\subsection{Results in Differences}

As discussed above, unobservables correlated with both community crime and community implementation of BLT may cause the coefficient estimates in the equations in levels to be biased. The standard way of accounting for this is to estimate the model in differences. Because we only have information on household crime victimization at one point in time we cannot difference the household level regressions in Table 5. What we can do though is include a variable that reflects whether there was any crime in the household's village prior to the BLT. This variable (Crime pre-BLT) is constructed from the PODES data and equals one if there was crime in the village prior to the introduction of BLT (between April 2004 and April 2005) and zero otherwise. Column 3 of Table 5 adds this variable. It is strongly significant but does not affect the statistical significance or magnitude of the BLT variables of interest.

The second and more formal way we control for baseline crime is to estimate a first differenced village level equation as in Equation 3. That is, we construct a village level variable from the 
Susenas household level data. This variable equals one if any household sampled in the village reported a crime, and equals zero otherwise. We then subtract the baseline village crime variable constructed from the PODES data (Crime pre-BLT) from this. Thus the dependent variable takes on three values $-1,0$ and 1 . Note that the PODES variable is a village level indicator of whether there was crime in the village. In contrast, the Susenas variable is calculated from crime reports from a sample of households in the village (stratified by expenditure). Thus the Susenas data will not capture all instances of crime in the village. This means that the differenced variable will understate increases in crime. As long as the enumeration areas sampled in the Susenas are representative of the extent of crime in a village our results will not be biased. ${ }^{25}$

Column 1 in Table 6 presents the estimation results. ${ }^{26}$ Our data do not allow us to construct changes in the independent variables so in Column 1 we are implicitly assuming no change in the $X$ 's in Equation 3. To assume they are largely unchanged over the period in question is not unreasonable given the nature of the variables and the short time period we are examining. Further specifications below add additional control variables. The results tell a very similar story to that in Table 5 . Leakage is a positive and strongly significant determinant of the change in village level crime. The presence of the BLT program is now only marginally significant $(\mathrm{p}=0.06)$. Undercoverage is now also significant $(\mathrm{p}=0.047)$. The results suggest that the program was associated with a 19 percent (1.7 percentage point) increase in the proportion of villages that went from experiencing no crime prior to the program to experiencing crime in the period following the introduction of the $\operatorname{program}^{27}$

Column 2 adds controls for a number of variables in levels. The rationale for doing this is that as this was a turbulent time with fuel prices increasing rapidly, the extent of any changes in crime rates may have depended on the initial conditions in each village. Several control variables are statistically significant. Many of these are the same variables that were significant in Table 5 , suggesting that crime is more likely to increase in villages that were more susceptible to crime per se. In addition to higher inequality, the presence of wealthy households and fewer men is

\footnotetext{
${ }^{25}$ The difference due to the different nature of the two data sets will simply be captured by the constant term in the regression. We estimated regressions with observations weighted to give greater weight to observations where the crime indicator from the Susenas is less likely to be an underestimate (weighting by the ratio of village sample size to village population). Doing this has very little impact on the results.

${ }^{26}$ For ease of interpretation we present the OLS results. Results from ordered logits are similar. Table 13 in the appendix shows the ordered logit results analogous to Table 6, column 3; the others are available from the authors on request.

${ }^{27}$ These magnitudes are calculated using estimates from the ordered logit regression shown in Table 13 in the appendix. We compare predictions from the model using the prevalence of the program and the extent of mistargeting found in the sample, with those predicted in the absence of the program.
} 
associated with a greater probability of crime increasing. Being in a rural area and having a greater percentage of the population involved in farming is also associated with a greater probability of crime increasing. These latter two variables may be proxying for distance from security forces. ${ }^{28}$ The variable reflecting ethnic homogeneity now shows that greater ethnic diversity increases the probability of village crime increasing, consistent with Demombynes and Özler (2005). The inclusion of the additional controls reduces the coefficient on the leakage variable but it remains strongly significant. The coefficients on undercoverage and the presence of the program remain positively signed but are now statistically insignificant. ${ }^{29}$ Column 3 of Table 6 adds district fixed effects. These control for any unobserved differences across districts that might affect changes in crime like conditions in regional labor markets, and cultural and political differences across regions. The key results are unchanged.

\section{Robustness Tests}

In this section we add additional control variables and estimate different specifications to test the robustness of our results.

\subsection{Changes in Security Arrangements}

The extent of security in a village is an obvious potential determinant of community crime. Variables reflecting security were not included in the previous regressions because of concern about their potential endogeneity. Column 1 of Table 7 adds variables that reflect whether the village built a security post in the last 12 months, whether there is a civilian defense organization-these are platoons formed in the village which are responsible for matters concerning security and order —or a police post in the village. As expected, all three variables are associated with a lower probability of crime increasing. Their inclusion does not affect the coefficients on the other variables in the regression. These results are consistent with previous findings that increased security measures lower crime rates (Levitt, 1997; Di Tella and Schargrodsky, 2004).

\footnotetext{
${ }^{28}$ Controlling for the share of households that are farm households also controls for the effects of increasing rice prices. Rice prices went up uniformly across Indonesia between 2005 and 2006. This led to farmer's income increasing over this time and could have led to greater "leakage" to what were now richer farm households. The rice price increases also reduced the real incomes of non-farm households and so the increased inequality could have given rise to increased crime. Thus higher rice prices could result in a non-causal association between crime and leakage of BLT funds. Controlling for the share of farm households and the share of farm laborers in the village will however capture this effect.

${ }^{29}$ We also examine whether crime was more likely to increase if the leakage was to more wealthy groups rather than to those just above the program's cut-off. We find no evidence of crime reacting more strongly to leakages to the very well-off.
} 


\subsection{Fuel-related Variables}

A possible concern with our results is that this was a time of considerable change. The BLT was introduced to offset the negative welfare effects of soaring fuel prices. Might it not be these fuel prices that are driving crime? First, note that if it was the case that poor families were resorting to crime to deal with the increase in fuel prices then we would expect to see the poverty indicators showing a positive relationship with changes in crime. This is not what we observe. All variables that reflect living standards are either insignificant or indicate a positive relationship between living standards and crime.

To examine this issue more closely, Column 2 in Table 7 adds some further variables which control for the extent to which fuel price increases impact upon the village. These are the percentage of households in the village that use electric lights (and hence not fuel), the percentage of households that use oil as their cooking fuel, the average share of transport costs in household expenditure and the average share of fuel costs in household expenditure. Having electric lights and spending a greater share on transport are statistically significant and their signs indicate a greater reliance on fuel is associated with a greater likelihood of crime increasing. The share of expenditure spent on fuel is also significant but negatively signed. The key finding however, is that inclusion of these variables does not substantively affect the coefficients on the BLT variables.

\subsection{Choice of Geographic Unit}

The anecdotal evidence suggests that the program gave rise to tensions within communities. For this reason, we have focused on the impact of mistargeting within a village on crime within that village. These communities are comprised of around 200-300 households. We are thus examining the effect of mistargeting in a relatively small geographic area on crime in that area. To examine the impact of our choice of geographic unit we now construct the targeting variables at the district level. Column 3 of Table 7 reports the results. The coefficients on the district level variables are consistent with our earlier results - greater leakage of funds to the non-poor across the district is associated with more crime. In this specification undercoverage of the poor within the district is also associated with greater crime, albeit with a smaller coefficient than leakage. When both community level and district level leakage variables are included as in Column 4, the district level variables remain significant and leakage within the community is significant. Thus, mistargeting in other communities also increases the village's crime rate. For example, mistargeting in villages close to Village A may cause some residents of those villages to turn to crime, some of which is 
conducted in Village A. ${ }^{30}$

\subsection{Village Administrator Characteristics}

A lingering concern is that the BLT variables might be proxying for something about the village which is also correlated with changes in crime. One likely candidate is village administration. As mentioned above in places where the BLT is poorly administered, there may be other administrative problems that cause crime. If these factors are non-time-varying then they are differenced out in the regressions in Table 6 . However, it is possible that the quality of village administration only matters in times of rapid change and crisis (so its effect is time-varying) and so it may be in poorly administered villages that we observe increases in crime. The PODES provides information on the age, gender and educational attainment of village heads, village secretaries, the head of the village community organization (Lembaga Pemberdayaan Masyarakat Desa, LPMD) and the head of the Village Legislative Body (Badan Perwakilan Desa, BPD). Column 1 in Table 8 shows that these variables are not jointly significant in a regression where the dependent variable is whether or not the village received the BLT program. This is as expected because village choice was determined by the Indonesian Statistical Agency (BPS). However Columns 2 and 3 show that these variables are jointly significant explanators of both types of targeting error within the village, although not in a uniform way. Column 4 shows that the inclusion of these variables does not affect the magnitude and statistical significance of our main targeting variables.

Another concern one may have about the role of village administration in generating our results is the potential for misreporting of crime by the village head in the PODES survey. If corrupt village heads systematically underreport crime in their village (for example, to cover their tracks if they are involved in organized crime) and also influence the targeting of BLT payments to benefit their cronies, then it will appear that crime increased by more in villages where there is greater leakage and possibly also where there is greater undercoverage. While we think such a mechanism is unlikely, and contrary to the structure of such crime in Indonesia (which is usually payment for protection and so paradoxically results in less crime events), we examine whether such misreporting might be driving our results. We do this by using information in the PODES on who was the survey respondent. In $53 \%$ of villages the village head is the only respondent but in $47 \%$ of villages at least one other respondent was involved (most commonly the village doctor, teacher,

\footnotetext{
${ }^{30}$ We do not relate district targeting error variables to changes in district crime because this does not allow us control for village characteristics that help explain variations in crime. It would also limit our sample to 439 observations. Adding district level variables in the household level regressions in Table 5 yields similar results.
} 
a representative of the village legislative body or a religious leader). In villages with more than one respondent it is less likely that the village head would have been able to underreport village crime. Column 5 in Table 7 re-estimates our preferred specification (Table 6, column 3) allowing for a differential effect of leakage and undercoverage on crime in villages that only had the village head as the respondent. The results show that in villages where only the village head was interviewed, our measure of the change in crime does indicate a larger increase in crime but the relationship between mistargeting and crime is no stronger than in villages with other respondents. The point estimate of the interaction term between mistargeting and having only the village head report is actually negative but not statistically significant. Hence, village heads' misreporting does not seem to be driving the relationship between mistargeting and village crime.

\subsection{Instrumental Variables}

A further way in which we allay fears about unobserved third variables is by instrumenting for the BLT targeting variables. We use BPS's administrative data for this purpose. We have access to the weights that BPS generated and that were used to assign households as being eligible or non-eligible. These weights differ across districts. We can thus generate the BPS score assigned to each household in our sample. ${ }^{31}$ We use this score to predict receipt of BLT for each household in our sample. Using this BPS determined eligibility in conjunction with the data on households' per capita expenditures from the Susenas we can then identify households that either a) are poor and BPS would not have identified to receive the payment; or b) are non-poor and BPS would have identified as being eligible. We then aggregate up within the villages to construct a measure of village leakage and undercoverage that is attributable to BPS and hence not correlated with unobservable village characteristics. We use these measures (Leakage BPS and Undercoverage $B P S)$ to instrument for the observed targeting errors. Note that as the crime regressions control for living standards, the BLT scores will only affect crime indirectly through BLT receipt.

Columns 1 and 2 in Table 9 show the first stage results. The regressions explain $19 \%$ and $24 \%$ of leakage and undercoverage respectively and the BPS mistargeting variables are strongly statistically significant $(\mathrm{p}<0.000$ in both cases). Column 3 shows the second stage results when

\footnotetext{
${ }^{31}$ We are unable to perfectly replicate the BPS score because the Susenas does not cover all of the variables used to construct the score. Specifically, the Susenas does not have variables indicating the frequency of meat $/$ chicken $/ \mathrm{milk}$ purchases per week, meal frequency, frequency of new clothes purchases; access to health clinics and assets. Except for assets we are able to use expenditure on these categories to construct proxies for the missing variables. We reweight the weights to ignore the asset variable. The resulting index thus closely resembles but is not identical to the BPS ranking of households. Approximately $30 \%$ of our sample received the BLT. Here we designate the $30 \%$ of the sample with the highest calculated BPS score as BPS recipients.
} 
district fixed effects are included. The coefficient on leakage remains significant but at the .10 level. The coefficient is however now much larger (increasing from 0.07 to 0.26 ). This suggests that our original estimates in Tables 5 and 6 were biased downward. Possible reasons for this will be discussed below.

One possible reason the standard errors on leakage increase when we instrument might be because a substantial portion of the variation in the predicted targeting variables that are used as instruments is across districts. This follows from BPS estimating different weighting functions for each district. Columns 4 and 5 show the results when provincial fixed effects are included rather than district level effects, and when no fixed effects are included. Leakage becomes strongly statistically significant and larger in magnitude. The magnitude of the effect is quite large. A one standard deviation increase in leakage to non-eligible households is associated with an increase in the dependent variable of somewhere between $9 \%$ and $16 \%$ of a standard deviation.

The increase in the magnitude of the coefficient on leakage once we instrument is consistent with a spurious negative correlation between increases in crime and mistargeting (not positive as would be the case if inept village administration was positively correlated with both poor targeting and increases in crime). It is also consistent with the way organized crime operates in Indonesian villages. Organized crime is widespread through villages across Indonesia and, as mentioned above, most commonly operates through payment for protection (Kristiansen, 2003). Hence, in villages where these powerful groups exist, not only are welfare payments captured but there is likely to also be less petty crime, ceteris paribus, as the extent of crime is controlled and limited by the criminal gangs. Using instrumental variables as we have done removes this effect. The instrumental variables result is thus consistent with program capture by powerful people in the village.

\subsection{Pre-Program Trends in Crime}

As a further check that the presence and mistargeting of BLT is not proxying for something correlated with changes in crime, we compare pre-BLT trends in crime in villages that did and did not have BLT recipients. We also compare the pre-BLT crime trend where there was lot of leakage and undercoverage with crime in villages where there was less. Figure 4 presents graphs of trends in incidence of crime from 2002 to 2005 (the share of villages in which crime was reported in the PODES data). There is no evidence of crime increasing more in villages with BLT recipients prior to the program. In fact, crime decreased by slightly more in these villages prior to the program. Similarly, the prevalence of crime decreased by slightly more in villages with higher leakage (above 
the median). Villages with higher undercoverage were also, if anything, experiencing a greater decline in crime than other villages prior to the program. Note though that all of these differences are very small and that none of the differences in the pre-program trend in crime are statistically significant (all p-values greater than 0.27). ${ }^{32}$

We do two things to more formally examine this issue. First, we add observations of pre-BLT crime in the 2003 PODES as independent variables in the regressions. Column 6 in Table 7 adds an indicator for whether there was a report of crime in the village in the 2003 PODES. The control for village crime in 2003 is statistically significant (reflecting its strong correlation with the crime rate immediately prior to the program). The coefficient on leakage remains positive and statistically significant. ${ }^{33}$

The final test we conduct to rule out the possibility that BLT is proxying for something unobserved that is correlated with crime is a falsification test using the 2000 Susenas and the 2000 PODES. The Susenas asks households about crime in the 1999 calendar year. The PODES asks a village representative about crime in the year to October 1999. The difference in these two reports thus reflects the difference between the amount of crime reported in October-December 1998 and that in October-December 1999. We use information about households in the Susenas sample and the BPS weights to construct a BPS score for each household. ${ }^{34}$ We then recreate our targeting measures using the BPS score to predict receipt of BLT, in the same way as in Section 7.5 above. That is, we compare the predicted receipt of BLT payment with the program's expenditure threshold (converted to 2000 Rupiah) and then calculate a measure of undercoverage and leakage for each village and an indicator of whether the program would have been active in the village. ${ }^{35}$ We then estimate a crime regression equivalent to Column 3 in Table 6 using these data. Column 7, Table 7 reports the results. While a number of the coefficients are statistically significant and similar in magnitude to the results in Table 6 (for example, rural status, village population and the gini coefficient), none of the BLT variables are statistically significant (all p-values are greater than $0.26) \cdot{ }^{36}$

\footnotetext{
${ }^{32}$ Differences in the pre-program level of crime likely reflect differences in socio-economic status which affect both program eligibility and crime which are controlled for in the regressions.

${ }^{33}$ If we add this variable to the household regressions reported in Table 5, it is not statistically significant and similarly does not affect the coefficient on the mistargeting variables. Note that adding this variable reduces the sample size as village codes change over time and not all of the villages in 2005 can be merged back to the 2003 data.

${ }^{34}$ Susenas 2000 does not provide information on the type of fuel used by households so we do not use this variable in the calculation of the BPS score. We rescale the weights so that they still sum to one.

${ }^{35}$ The 2000 cut-off used is the per capita expenditure at the same percentile of the distribution as Rp175,000 in 2005.

${ }^{36}$ There are a number of other falsification tests that can be conducted. One can examine whether the predicted
} 


\section{Understanding the Mechanism}

The results above demonstrate that leakage of BLT funds to the non-poor is associated with increased crime. We now examine potential mechanisms through which this effect might operate. The crime literature surveyed in Section 2 identifies inequality and social capital (or trust) as important determinants of crime. In this section we examine whether BLT increased crime through these intermediate variables.

\subsection{Inequality}

While the mistargeting of the program arbitrarily induced changes to the distribution of income within the village, in most villages the change in inequality as measured by the Gini coefficient was small. ${ }^{37}$ The Susenas data show that the BLT resulted in increases in inequality in $20 \%$ of villages and decreases in inequality in the remaining $80 \%$. In results that are available from the authors upon request, we add controls for the change in the community Gini coefficient associated with the BLT program (to both household level and village level regressions). The variable is not statistically significant ( $\mathrm{p}>0.6$ in both cases) and does not affect the coefficients on the other variables. We also construct a measure of the change in the rank of households (when ranked by per capita expenditure before and after the program) within the village. This variable is also not statistically significant. $^{38}$ Therefore, we can conclude that it does not seem to be the case that increases in inequality due to BLT are causing the increases in crime.

\subsection{Social Capital}

We have hypothesized that, consistent with sociological theory, social capital is an avenue via which mistargeting may affect crime. Mistargeting may cause feelings of mistrust in the community and so diminish the ability of the community to work together. This may make the community more susceptible to crime by both inducing criminal acts and reducing the community's effectiveness at combatting crime. The Susenas and PODES data do not provide detailed information on social capital. To examine the impact of the program on social capital we use data from the Indonesian

mistargeting in 2000 is a determinant of the change in crime between 2000 and 2002 (as captured in the Susenas 2000 data and PODES 2002 data respectively). It is not. One can also examine whether actual mistargeting in 2005 can predict the change in crime between 2002 and 2005 (as captured in the PODES 2002 and PODES 2005). It cannot. Results available on request.

${ }^{37}$ We examine this by calculating the Gini coefficient using household expenditures as reported in the Susenas. We then recalculate the Gini coefficients, subtracting off the amount of the BLT transfer from household expenditure in recipient households.

${ }^{38}$ The rank measure was calculated as the sum of the absolute difference of the change in rank, normalized by the village sample size. 
Family Life Survey (IFLS). The IFLS is a longitudinal household survey that is representative of $83 \%$ of the Indonesian population (13 out of Indonesia's 33 provinces). It consists of four waves of data, collected in 1993, 1997, 2000 and 2007. ${ }^{39}$ The fourth round (IFLS4) is thus conducted about two years after the implementation of the 2005 BLT. IFLS4 covers approximately 13,000 household and asks individual respondents whether they were a victim of crime in the previous 12 months.

In Column 1 of Table 10, we establish that the same relationship between the level of crime and BLT mistargeting that was found in the Susenas data is also evident in the IFLS data. That is, the greater the proportion of non-eligible households that received the BLT payment, the higher is crime in the village. Unfortunately, previous waves of the IFLS do not collect crime data so we cannot look at the effect of the program on changes in crime.

Both the 2000 and 2007 waves of the IFLS collect detailed information on individuals' participation in community groups. This is an often used proxy for community social capital. We use these data to examine the impact of program mistargeting on community participation, controlling for the level of pre-program participation. Specifically, we construct a measure of how many groups the individual participated in during the previous 12 months, for each of the two waves of the data. The number of groups individuals participate in ranges from 0 to 18 , with a mean of 1.5 in 2007.40

Column 2 of Table 10 shows that social capital is negatively affected by the extent of leakage of BLT funds. Columns 3 and 4 disaggregate by gender and show that this finding is driven by women's responses to leakage. An additional $10 \%$ of non-poor households receiving BLT reduces the mean number of groups a woman participates in by 0.075 (6\% at the mean). Men's participation is unaffected by leakage. BLT undercoverage is negatively signed but not statistically significant for either gender. ${ }^{41}$ Women's social capital being more responsive to the misallocation of resources is consistent with findings in the experimental economics literature that women are more concerned with the welfare of others and fairness than men, (Eckel and Grossman, 1998).

Although the IFLS does not provide longitudinal data on the crime rate, IFLS4 does ask a community leader to compare village safety in 2007 to village safety in 2000 . The answer is given on a 5 point scale from Much Safer (1) to Much Less Safe (5). We are thus able to examine whether

\footnotetext{
${ }^{39}$ See http://www.rand.org/labor/FLS/IFLS/ for more details.

${ }^{40}$ Many community groups are predominantly for men or women only. Our measures for both genders reflect participation in community rotating savings associations (arisan), community meetings, community cooperatives, voluntary labor programs and programs to improve the neighborhood. In addition for women there are women's associations and child weighing posts. For men, there are neighborhood security groups, water supply committees and garbage disposal committees.

${ }^{41}$ The household level variables BLT-poor and No BLT-poor are also significant. For both men and women, these two variables are not significantly different from one another and so jointly indicate that poorer households are less likely to participate in 2007, controlling for the level of participation in 2000.
} 
declines in social capital are associated with a decline in the perception of community safety which will reflect the extent of crime in the village. Column 5 in Table 10 reports the results. Although the sample size is small with only one observation for each of the 310 villages, we find that people do perceive the community to be less safe $(\mathrm{p}=0.09) .{ }^{42}$

The results above show that leakage of funds to the non-poor is associated with decreases in social capital and a decrease in the perception of safety in the villages. So far we have not said much about who is perpetrating the crimes. It could be that the mistargeting within the community causes people to turn on one another within that community. It is also possible that by weakening social capital, the community becomes more vulnerable to pre-existing criminality, be it from within or from outside the village. That the change in women's social capital is responsive to the leakage of BLT funds to non-eligible households but men's is not allows us to hypothesize on this point. It suggests that the mistargeting of the program may not have increased the propensity of individuals to engage in crime (as men are the main perpetrators of crime) but rather may have made the community more susceptible to existing levels of criminality by weakening social cohesion and hence the community's ability to protect itself. For example, it may have made people less likely to look out for one another and share information on recent incidences of crime within the village.

\section{Discussion and Conclusion}

The findings presented above suggest that a poorly targeted and administered program can significantly disturb the social fabric within a community, to the extent that people disengage from the community. This makes it more susceptible to crime. Crime has its own immediate costs but there are also other intangible consequences of such disruption. Most worrying perhaps is the impact that this has on social cohesion and the willingness and ability to work together for the betterment of the community in the future. This is one facet of the BLT program that village heads made explicit in group discussions (Hastuti et al., 2006a) and that is backed up by our findings using the IFLS data.

The results strongly suggest that leakage of payments to the non-poor fans the flames of social

\footnotetext{
${ }^{42}$ The IFLS data also collected information on perceptions of corruption which allow us to directly examine whether the mistargeting measures are proxying for corrupt village administration. In particular it asked individual respondents to rank governance in this village on a 4 point scale from very good (1) to Very bad (4). They were then asked how this compared to $2000(1=$ much better to $4=$ much worse) and whether there were currently any cases of corruption involving the village office. We construct means of these responses at the village level and add these as explanatory variables in the IFLS crime regression. None of the measures are close to being statistically significant and their inclusion does not affect the coefficient on the BLT variables. Results available on request.
} 
unrest. Some specifications suggest that eligible recipients missing out on the payment also contributes to increases in crime but this evidence is less robust and the impact smaller in magnitude. It is well established within the social psychology literature that "sins of commission" are judged more harshly and invoke a stronger emotional response than "sins of omission" (for example see Ritov and Baron (1992), Baron and Ritov (1994) and Spranca et al. (1991)). A sin of commission is one in which a person acts in a harmful way. In contrast, an act of omission is one where by omitting to act, a person harms someone. In this framework leakage of payments to the non-poor can be viewed as a sin of commission because an action was taken to allocate the money to the non-poor. Undercoverage of the poor however is a sin of omission: the poor are harmed by no action being taken to allocate the money to them. ${ }^{43}$ Note also that undercoverage preserves the status quo. Experiments show that people have a strong preference for the status quo (Ritov and Baron, 1992). This "status quo bias" may further dampen the emotional response to the poor missing out on the program. For both these reasons, communities may judge leakage of funds to better-off households more harshly than the non-allocation of funds to the poor. Consequently, the emotional reaction to leakage is stronger and more crime results.

In conclusion, our findings suggest that the negative effects of poorly administering a transfer program could extend well beyond the monetary value of leaked funds. This study underscores the importance of targeting programs in a way that is acceptable to the affected communities. Program acceptance can be enhanced by improving targeting accuracy and by transparent communication of this mechanism and the program's aims to the general population. Recent work by Alatas et al. (2011) finds that involving the community in the targeting process substantially improves community satisfaction. This is an area for further research.

\footnotetext{
${ }^{43}$ Kahneman and Miller (1986) argue that individuals perceive outcomes as being worse when they can easily imagine that a better outcome could have occurred. When an action has occurred it is easy to imagine the result of inaction, so it invokes a stronger emotional reaction. When harm is caused by inaction, imagining the result of action is more difficult, so the response is not so strong.
} 


\section{References}

Alatas, V., A. Banerjee, R. Hanna, B. Olken, and J. Tobias, "How to Target the Poor: Evidence from a Field Experiment in Indonesia," American Economic Review, forthcoming 2011.

Anderson, D.M., "The Effects of Poverty on the Susceptibility to Crime in South Africa," 2008. Dept of Economics, University of Washington Working Paper.

Baron, J. and I. Ritov, "Reference Points and Omission Bias," Organizational Behaviour and Human Decision Processes, 1994, 59, 475-498.

Berger, P. and R. Neuhaus, To Empower People: From State to Civil Society, Washington, D.C.: American Enterprise Institute, 1996.

Bourguignon, F., "Crime, Violence and Inequitable Development," 1999. Paper presented at Annual World Bank Conference on Development Economics.

BPS, Metodologi Penentuan Rumah Tangga Miskin: Pendataan Sosial Ekonomi Penduduk 2005, Jakarta, Indonesia: Badan Pusat Statistik, 2005.

Bursik, R. J. and H. G. Grasmick, Neighborhoods and Crime: The Dimensions of Effective Community Control, New York, NY: Macmillan, 1993.

Coady, D., M. Grosh, and J. Hoddinott, Targeting of Transfers in Developing Countries: Review of Lessons and Experience, Washington, DC: World Bank, 2004.

Coleman, J. S., Foundations of Social Theory, Cambridge, MA: Harvard University Press, 1990.

Demombynes, G. and B. Özler, "Crime and Local Inequality in South Africa," Journal of Development Economics, 2005, 76 (2), 265-292.

Di Tella, R. and E. Schargrodsky, "Do Police Reduce Crime? Estimates Using the Allocation of Police Forces after a Terrorist Attack," American Economic Review, 2004, 94 (1), 115-133.

Eckel, C. and P. Grossman, "Are Women Less Selfish than Men?: Evidence from Dictator Experiments," Economic Journal, May 1998, 108, 726-735.

Fafchamps, M. and C. Moser, "Crime, Isolation, and Law Enforcement," Journal of African Economies, 2003, $12(4), 625-671$.

Fajnzylber, P., D. Lederman, and N. Loayza, "Inequality and violent crime," Journal of Law and Economics, 2002, $45(1), 1-40$.

Gibson, J. and K. Bonggeun, "Measurement Error and the Effect of Inequality on Experienced versus Reported Crime," 2006. Working Papers in Economics 06/05, University of Waikato, Department of Economics.

Gugerty, M. and M. Kremer, "Outside Funding of Community Organizations: Benefiting or Displacing the Poor?," 2002. NBER Working Paper, No. 7896.

Hastuti, N. Toyamah, S. Usman, B. Sulaksono, S. Budiyati, W. Widyanti, M. Rosfadhila, H. Sadaly, S. Erlita, R. Sodo, S. Bazzi, and S. Sumarto, "A Rapid Appraisal of the Implementation of the 2005 Direct Cash Transfer Program in Indonesia: A Case Study of Five Kabupaten/Kota," July 2006. SMERU REsearch Report.

_, S. Sumarto, S. Usman, B. Sulaksono, S. Budiyati, W. Widyanti, R. Fillaili, D. Suryadarma, M. Rosfadhila, H. Sadaly, and S. Erlita, "Kajian Cepat Pelaksanaan Subsidi Langsung Tunai Tahun 2005 di Indonesia: Studi Kasus di Provinsi DKI Jakarta," Dec 2006. SMERU REsearch Report.

Kahneman, D. and D. Miller, "Norm Theory: Comparing Reality to its Alternatives," Psychological Review, 1986, 93, 136-153.

Kristiansen, S., "Violent Youth Groups in Indonesia: The Cases of Yogyakarta and Nusa Tenggara Barat.," SOJOURN - Journal of Social Issues in South East Asia, 2003, 18 (1), 110-138. 
Levitt, S. D., "Using Electoral Cycles in Police Hiring to Estimate the Effect of Police on Crime," American Economic Review, 1997, 87 (3), 270-290.

Parker, S., "Case Study: The Oportunidades Program in Mexico," 2003. Paper presented at Shanghai Poverty Conference - Scaling Up Poverty Reduction.

Pritchett, L., S. Sumarto, and A. Suryahadi, "Targeted Programs in an Economic Crisis: Empirical Findings from the Experience of Indonesia," October 2002. SMERU Working Paper.

Putnam, R., Bowling Alone: The Collapse and Revival of American Community, New York, N.Y.: Simon and Schuster, 2000.

Ritov, I. and J. Baron, "Status-quo and Omission Bias," Journal of Risk and Uncertainty, 1992, 5, 49-61.

Rosenfeld, R. and S. F. Messner, "Beyond the Criminal Justice System: Anomie, Institutional Vitality, and Crime in the United States," 1998. Paper presented at the meeting of the American Sociological Association.

Satriana, S., "Impact Assessment of the 2008 Unconditional Cash Transfer Programme (BLT) in Indonesia," 2009. Masters Thesis. Maastricht Graduate School of Governance.

Spranca, M., E. Minsk, and J. Baron, "Omission and Commission in Judgement and Choice," Journal of Experimental Social Psychology, 1991, 27, 76-105.

Widjaja, M., "An Economic and Social Review on Indonesian Direct Cash Transfer Program to Poor Families Year 2005," 2009. Paper presented at the Association for Public Policy Analysis and Management International Conference.

World Bank, Making the New Indonesia Work for the Poor, Washington, DC: World Bank, 2006. 
Table 1: Targeting Performance

\% Receiving BLT BLT Households \% of BLT recipients (millions)

(1) (2)

(3)

\begin{tabular}{lccc}
\hline \hline & 53.5 & 8.7 & \\
Poor & 16.5 & 6.5 & 43.1 \\
Non-poor & & & \\
By Income Quintile: & 60 & 6.6 & 43.5 \\
Q1 & 35.4 & 4 & 26.2 \\
Q2 & 23.2 & 2.6 & 16.8 \\
Q3 & 13.9 & 1.5 & 9.9 \\
Q4 & 4.8 & 0.6 & 3.7 \\
Q5 & 27.5 & 15.4 & 100 \\
All & & & \\
\hline
\end{tabular}

Note: Poor and non-poor are defined to coincide with the eligibility criteria. 
Table 2: BLT and Social Unrest

\begin{tabular}{lc}
\hline Type of Incident & \% of Villages \\
\hline \hline & \\
Protests & 34.6 \\
Injured Victims & 14.9 \\
Threats to Village Officials & 11.8 \\
Threats to BPS Staff & 4.4 \\
Vandalism to Public Facilities & 1.5 \\
Conflict Among Citizens & 1.4 \\
\end{tabular}

Source: Widjaja (2009) 


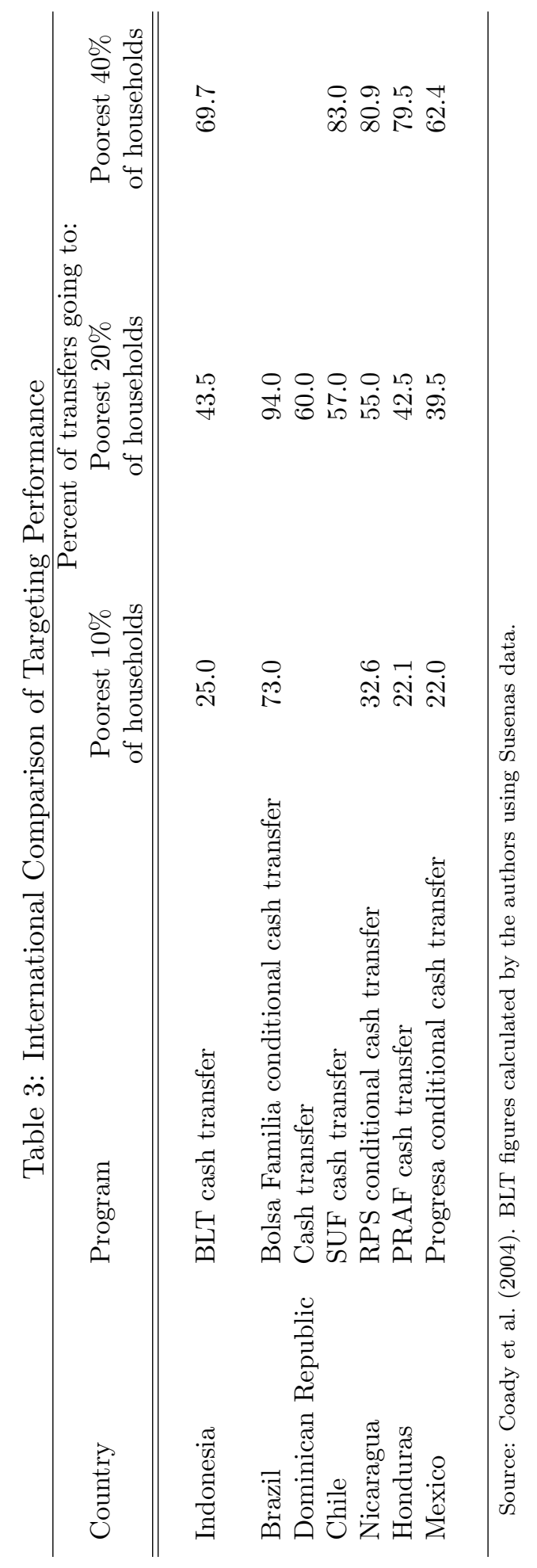


Table 4: Summary Statistics of Key Variables

\begin{tabular}{|c|c|c|c|c|c|}
\hline Variable & $\mathbf{N}$ & Mean & Std. Dev. & Min & $\operatorname{Max}$ \\
\hline \multicolumn{6}{|l|}{ Household Level Variables : } \\
\hline crime $_{i v t}$ & 262476 & 0.028 & 0.164 & 0 & 1 \\
\hline BLT-poor & 262476 & 0.160 & 0.367 & 0 & 1 \\
\hline BLT-non-poor & 262476 & 0.132 & 0.339 & 0 & 1 \\
\hline No BLT-poor & 262476 & 0.128 & 0.334 & 0 & 1 \\
\hline In second top decile & 262476 & 0.101 & 0.301 & 0 & 1 \\
\hline In top decile & 262476 & 0.102 & 0.302 & 0 & 1 \\
\hline \multicolumn{6}{|l|}{ Village Level Variables } \\
\hline$\Delta$ crime $_{v t}$ & 14815 & -0.274 & 0.641 & -1 & 1 \\
\hline Violent crime pre-BLT & 14815 & 0.131 & 0.337 & 0 & 1 \\
\hline BLT present & 14815 & 0.878 & 0.328 & 0 & 1 \\
\hline Leakage & 14815 & 0.206 & 0.243 & 0 & 1 \\
\hline Undercoverage & 14815 & 0.349 & 0.355 & 0 & 1 \\
\hline Leakage (district) & 14815 & 0.206 & 0.131 & 0.018 & 0.943 \\
\hline Undercoverage (district) & 14815 & 0.465 & 0.163 & 0 & 1 \\
\hline$\%$ households eligible & 14815 & 0.307 & 0.290 & 0 & 1 \\
\hline Rural & 14815 & 0.676 & 0.468 & 0 & 1 \\
\hline Proportion in second top decile & 14815 & 0.093 & 0.115 & 0 & 0.813 \\
\hline Proportion in top decile & 14815 & 0.087 & 0.161 & 0 & 1 \\
\hline Gini coefficient & 14815 & 0.210 & 0.075 & 0 & 0.81 \\
\hline Average per capita expenditure (million Rp) & 14815 & 0.259 & 0.153 & 0.039 & 5.41 \\
\hline Population (thousands) & 14815 & 0.541 & 6.725 & 0.042 & 79.0 \\
\hline Male share & 14815 & 0.499 & 0.033 & 0.01 & 0.98 \\
\hline Farm households & 14815 & 0.63 & 0.339 & 0 & 1 \\
\hline Farm laborers & 14815 & 0.067 & 0.107 & 0 & 0.975 \\
\hline Poor letter & 14815 & 0.071 & 0.128 & 0 & 1 \\
\hline Hours to city & 14815 & 0.42 & 0.79 & 0.02 & 13.5 \\
\hline One ethnic group & 14815 & 0.732 & 0.443 & 0 & 1 \\
\hline Security post & 14815 & 0.841 & 0.370 & 0 & 1 \\
\hline Civilian defense & 14815 & 0.878 & 0.327 & 0 & 1 \\
\hline Police post & 14815 & 0.208 & 0.406 & 0 & 1 \\
\hline Electric lights & 14815 & 0.790 & 0.407 & 0 & 1 \\
\hline Cook with fuel & 14815 & 0.370 & 0.257 & 0 & 1 \\
\hline Transport share & 14815 & 0.041 & 0.053 & 0 & 0.774 \\
\hline Fuel share & 14815 & 0.086 & 0.046 & 0 & 0.567 \\
\hline$\Delta$ Gini coefficient & 14815 & -0.007 & 0.012 & -0.139 & 0.15 \\
\hline$\Delta$ crime $_{v t}$ Pre-BLT) & 14815 & -0.25 & 0.590 & -1 & 1 \\
\hline Leakage_BLS & 14815 & 0.317 & 0.270 & 0 & 1 \\
\hline Undercoverage_BPS & 14815 & 0.335 & 0.348 & 0 & 1 \\
\hline
\end{tabular}


Table 5: Household Level Crime Regressions

\begin{tabular}{|c|c|c|c|c|}
\hline & $(1)$ & $(2)$ & $(3)$ & $(4)$ \\
\hline Dependent Variable: & crime $_{i v t}$ & crime $_{i v t}$ & crime $_{i v t}$ & crime $_{i v t}$ \\
\hline BLT-poor & & $\begin{array}{c}-.0009 \\
(.001)\end{array}$ & $\begin{array}{c}-.0009 \\
(.001)\end{array}$ & $\begin{array}{l}-.001 \\
(.001)\end{array}$ \\
\hline BLT-non-poor & & $\begin{array}{c}-.004 \\
(.001)^{* * *}\end{array}$ & $\begin{array}{c}-.004 \\
(.001)^{* * *}\end{array}$ & $\begin{array}{c}-.005 \\
(.001)^{* * *}\end{array}$ \\
\hline No BLT-poor & & $\begin{array}{l}-.001 \\
(.001)\end{array}$ & $\begin{array}{l}-.001 \\
(.001)\end{array}$ & $\begin{array}{c}-.0008 \\
(.001)\end{array}$ \\
\hline BLT present & & $\begin{array}{c}.007 \\
(.002)^{* * *}\end{array}$ & $\begin{array}{c}.006 \\
(.002)^{* * *}\end{array}$ & $\begin{array}{c}.008 \\
(.002)^{* * *}\end{array}$ \\
\hline Leakage & &.$_{(.003)^{* * *}}$ & $\frac{.01}{(.003)^{* * *}}$ & $\frac{.01}{(.003)^{* * *}}$ \\
\hline Undercoverage & & $\begin{array}{l}-.001 \\
(.002)\end{array}$ & $\begin{array}{l}-.001 \\
(.002)\end{array}$ & $\begin{array}{l}.0008 \\
(.002)\end{array}$ \\
\hline Crime pre-BLT & & & $\begin{array}{c}.005 \\
(.001)^{* * *}\end{array}$ & $\begin{array}{c}.003 \\
(.001)^{* * *}\end{array}$ \\
\hline In second top decile $(0 / 1)$ & $\begin{array}{l}.001 \\
(.001)\end{array}$ & $\begin{array}{l}.0004 \\
(.001)\end{array}$ & $\begin{array}{l}.0004 \\
(.001)\end{array}$ & $\begin{array}{l}.0004 \\
(.001)\end{array}$ \\
\hline In top decile $(0 / 1)$ & $\begin{array}{c}.005 \\
(.002)^{* * *}\end{array}$ & $\begin{array}{c}.004 \\
(.002)^{* *}\end{array}$ & $\begin{array}{c}.004 \\
(.002)^{* *}\end{array}$ & $\begin{array}{c}.004 \\
(.002)^{* *}\end{array}$ \\
\hline$\%$ households eligible & $\begin{array}{l}.002 \\
(.002)\end{array}$ & $\begin{array}{l}.002 \\
(.003)\end{array}$ & $\begin{array}{l}.002 \\
(.003)\end{array}$ & $\begin{array}{c}-.008 \\
(.003)^{* * *}\end{array}$ \\
\hline Rural & $\begin{array}{l}-.001 \\
(.001)\end{array}$ & $\begin{array}{l}-.001 \\
(.001)\end{array}$ & $\begin{array}{c}-.0009 \\
(.001)\end{array}$ & $\begin{array}{c}-.0002 \\
(.002)\end{array}$ \\
\hline Proportion hholds in 2nd top decile & $\begin{array}{l}-.003 \\
(.006)\end{array}$ & $\begin{array}{c}-.0004 \\
(.006)\end{array}$ & $\begin{array}{c}-.0003 \\
(.006)\end{array}$ & $\begin{array}{c}.01 \\
(.006)^{*}\end{array}$ \\
\hline Proportion hholds in top decile & $\begin{array}{c}.02 \\
(.007)^{* * *}\end{array}$ & $\begin{array}{c}.02 \\
(.007)^{* * *}\end{array}$ & $\begin{array}{c}.02 \\
(.007)^{* * *}\end{array}$ & $\begin{array}{c}.02 \\
(.007)^{* * *}\end{array}$ \\
\hline Gini coefficient & $\begin{array}{c}.05 \\
(.008)^{* * *}\end{array}$ & $\begin{array}{c}.04 \\
(.008)^{* * *}\end{array}$ & $\begin{array}{c}.04 \\
(.008)^{* * *}\end{array}$ & $\begin{array}{c}.04 \\
(.008)^{* * *}\end{array}$ \\
\hline Average per capita expenditure & $\begin{array}{l}.0009 \\
(.007)\end{array}$ & $\begin{array}{l}.002 \\
(.008)\end{array}$ & $\begin{array}{l}.002 \\
(.008)\end{array}$ & $\begin{array}{l}-.004 \\
(.007)\end{array}$ \\
\hline Village population & $\begin{array}{c}.0002 \\
(.0001)^{* *}\end{array}$ & $\begin{array}{c}.0002 \\
(.0001)^{* * *}\end{array}$ & $\begin{array}{c}.0002 \\
(.0001)^{* *}\end{array}$ & $\begin{array}{l}-.0002 \\
(.0001)^{*}\end{array}$ \\
\hline Male share & $\begin{array}{l}-.03 \\
(.01)^{*}\end{array}$ & $\begin{array}{l}-.03 \\
(.01)^{*}\end{array}$ & $\begin{array}{l}-.03 \\
(.01)^{* *}\end{array}$ & $\begin{array}{l}-.02 \\
(.01)\end{array}$ \\
\hline Farm households & $\begin{array}{l}.0009 \\
(.002)\end{array}$ & $\begin{array}{c}-.0002 \\
(.002)\end{array}$ & $\begin{array}{l}.0003 \\
(.002)\end{array}$ & $\begin{array}{l}-.001 \\
(.002)\end{array}$ \\
\hline Farm laborers & $\begin{array}{l}-.004 \\
(.004)\end{array}$ & $\begin{array}{l}-.002 \\
(.004)\end{array}$ & $\begin{array}{l}-.004 \\
(.004)\end{array}$ & $\begin{array}{l}-.002 \\
(.005)\end{array}$ \\
\hline Poor letter & $\begin{array}{c}-.0005 \\
(.004)\end{array}$ & $\begin{array}{l}-.002 \\
(.004)\end{array}$ & $\begin{array}{l}-.002 \\
(.004)\end{array}$ & $\begin{array}{l}-.006 \\
(.004)\end{array}$ \\
\hline Hours to city & $\begin{array}{c}.002 \\
(.0009)^{* * *}\end{array}$ & $\begin{array}{c}.002 \\
(.0009)^{* *}\end{array}$ & $\begin{array}{c}.002 \\
(.0009)^{* *}\end{array}$ & $\begin{array}{c}.002 \\
(.0009)^{* *}\end{array}$ \\
\hline One ethnic group & $\begin{array}{l}.001 \\
(.001)\end{array}$ & $\begin{array}{l}.002 \\
(.001)\end{array}$ & $\begin{array}{l}.001 \\
(.001)\end{array}$ & $\begin{array}{l}.001 \\
(.001)\end{array}$ \\
\hline Fixed effects & No & No & No & District \\
\hline R-squared & .002 & .003 & .003 & .01 \\
\hline $\mathrm{N}$ & 262476 & 262476 & 262476 & 262476 \\
\hline
\end{tabular}

Notes: We report results from OLS regressions where the dependent variable is a dichotomous variable if the household experienced a crime. All specifications are clustered at the village level. $* * *$ indicates significance at $1 \%$ level, ${ }^{* *}$ at $5 \%$ level, ${ }^{*}$ at $10 \%$ level. 
Table 6: Village Level Crime Regressions

\begin{tabular}{|c|c|c|c|}
\hline & $(1)$ & $(2)$ & $(3)$ \\
\hline Dependent Variable: & $\Delta$ crime $_{v t}$ & $\Delta$ crimevt & $\Delta$ crime $_{v t}$ \\
\hline BLT present & $\begin{array}{c}.03 \\
(.02)^{*}\end{array}$ & $\begin{array}{l}.03 \\
(.02)\end{array}$ & $\begin{array}{c}.04 \\
(.02)^{*}\end{array}$ \\
\hline Leakage & $\begin{array}{c}.19 \\
(.02)^{* * *}\end{array}$ & $\begin{array}{c}.11 \\
(.02)^{* * *}\end{array}$ & $\begin{array}{c}.08 \\
(.03)^{* * *}\end{array}$ \\
\hline Undercoverage & $\begin{array}{c}.03 \\
(.02)^{* *}\end{array}$ & $\begin{array}{l}.03 \\
(.02)\end{array}$ & $\begin{array}{l}.03 \\
(.02)\end{array}$ \\
\hline$\%$ households eligible & & $\begin{array}{l}-.03 \\
(.03)\end{array}$ & $\begin{array}{l}-.06 \\
(.03)^{* *}\end{array}$ \\
\hline Rural & & $\begin{array}{c}.04 \\
(.02)^{* *}\end{array}$ & $\begin{array}{l}.03 \\
(.02)\end{array}$ \\
\hline Proportion hholds in 2nd top decile & & $\begin{array}{l}.05 \\
(.06)\end{array}$ & $\begin{array}{l}.05 \\
(.06)\end{array}$ \\
\hline Proportion hholds in top decile & & $\begin{array}{c}.26 \\
(.07)^{* * *}\end{array}$ & $\begin{array}{c}.23 \\
(.07)^{* * *}\end{array}$ \\
\hline Gini coefficient & & $\begin{array}{c}.34 \\
(.08)^{* * *}\end{array}$ & $\begin{array}{c}.26 \\
(.08)^{* * *}\end{array}$ \\
\hline Average per capita expenditure & & $\begin{array}{l}-.01 \\
(.07)\end{array}$ & $\begin{array}{l}-.07 \\
(.07)\end{array}$ \\
\hline Village population & & $\begin{array}{c}-.007 \\
(.001)^{* * *}\end{array}$ & $\begin{array}{c}-.006 \\
(.001)^{* * *}\end{array}$ \\
\hline Male share & & $\begin{array}{c}-.41 \\
(.16)^{* * *}\end{array}$ & $\begin{array}{l}-.33 \\
(.17)^{* *}\end{array}$ \\
\hline Farm households & & ${ }_{(.03)^{* * *}}$ & $\begin{array}{l}.05 \\
(.03)^{*}\end{array}$ \\
\hline Farm laborers & & $\begin{array}{c}-.32 \\
(.05)^{* * *}\end{array}$ & $\begin{array}{l}-.03 \\
(.06)\end{array}$ \\
\hline Poor letter & & $\begin{array}{l}.02 \\
(.04)\end{array}$ & $\begin{array}{l}-.06 \\
(.04)\end{array}$ \\
\hline Hours to city & & $\begin{array}{c}.04 \\
(.007)^{* * *}\end{array}$ & $(.008)^{* * *}$ \\
\hline One ethnic group & & $\begin{array}{c}-.1 \\
(.01)^{* * *}\end{array}$ & $\begin{array}{c}-.07 \\
(.01)^{* * *}\end{array}$ \\
\hline Constant & $\begin{array}{c}-.35 \\
(.02)^{* * *}\end{array}$ & $\begin{array}{l}-.18 \\
(.09)^{* *}\end{array}$ & $\begin{array}{l}-.18 \\
(.09)^{*}\end{array}$ \\
\hline Fixed Effects: & No & No & District \\
\hline R-squared & .006 & .03 & .01 \\
\hline $\mathrm{N}$ & 14815 & 14815 & 14815 \\
\hline
\end{tabular}

Notes: We report results from OLS regressions where the dependent variable is an indicator of the change in crime from 2005 to 2006 where 1 indicates that crime has increased; 0 indicates no change; -1 indicates that crime has decreased. Standard errors are shown in parentheses. $* * *$ indicates significance at $1 \%$ level, ** at $5 \%$ level, * at $10 \%$ level. 
Table 7: Robustness Tests

\begin{tabular}{|c|c|c|c|c|c|c|c|}
\hline & $(1)$ & $(2)$ & $(3)$ & $(4)$ & $(5)$ & $(6)$ & $(7)$ \\
\hline Dependent Variable: & & & $\bar{\Delta}_{\Delta \text { crime }_{v t}}$ & & & & $\begin{array}{l}\Delta \text { crime }_{v t} \\
(\text { Pre-BLT) }\end{array}$ \\
\hline BLT present & $(.03)^{*}$ & $\begin{array}{c}.04 \\
(.02)^{* *}\end{array}$ & $(.04)^{* *}$ & $\begin{array}{l}.03 \\
(.02)^{*}\end{array}$ & $(.04)^{*}$ & $\begin{array}{l}.04 \\
(.02)\end{array}$ & $\begin{array}{l}-.07 \\
(.07)\end{array}$ \\
\hline Leakage & $(.03)^{* * *}$ & $(.03)^{* * *}$ & & $(.03)^{* * *}$ & $(.04)^{* * *}$ & $(.03)^{* *}$ & $\begin{array}{l}-.004 \\
(.06)\end{array}$ \\
\hline Undercoverage & $\begin{array}{l}.03 \\
(.02)\end{array}$ & $\begin{array}{c}.03 \\
(.02)^{*}\end{array}$ & & $\begin{array}{l}.02 \\
(.02)\end{array}$ & $\begin{array}{l}.03 \\
(.02)\end{array}$ & $\begin{array}{l}.03 \\
(.02)\end{array}$ & $\begin{array}{l}-.02 \\
(.04)\end{array}$ \\
\hline District Leakage & & & $(.07)^{* * *}$ & $(.07)^{* *}$ & & & \\
\hline District Undercoverage & & & $(.05)^{* *}$ & $(.05)^{* *}$ & & & \\
\hline Only Village Head Reporting & & & & & $\begin{array}{l}0.05 \\
(.02)^{* *}\end{array}$ & & \\
\hline Leakage x Only Village Head Reporting & & & & & $\begin{array}{c}-0.05 \\
(.05)\end{array}$ & & \\
\hline Undercoverage x Only Village Head Reporting & & & & & $\begin{array}{c}-0.001 \\
(.03)\end{array}$ & & \\
\hline Crime in 2003 & & & & & & $(.01)^{* * *}$ & \\
\hline$\%$ Households Eligible & $(.03)^{* *}$ & $(.03)^{* *}$ & $(.03)^{*}$ & $\begin{array}{l}-.03 \\
(.03)\end{array}$ & $(.03)^{* *}$ & $\begin{array}{c}0.08 \\
(.03)^{* *}\end{array}$ & $\begin{array}{l}-.12 \\
(.5)\end{array}$ \\
\hline Rural & $\begin{array}{l}.02 \\
(.02)\end{array}$ & $\begin{array}{l}.02 \\
(.02)\end{array}$ & $(.02)^{* *}$ & $(.02)^{* *}$ & $\begin{array}{l}.03 \\
(.02)\end{array}$ & $\begin{array}{l}.02 \\
(.02)\end{array}$ & $(.02)^{* *}$ \\
\hline Proportion hholds in 2nd top decile & $\begin{array}{l}.05 \\
(.06)\end{array}$ & $\begin{array}{l}.05 \\
(.06)\end{array}$ & $\begin{array}{l}.02 \\
(.06)\end{array}$ & $\begin{array}{l}.05 \\
(.06)\end{array}$ & $\begin{array}{l}.05 \\
(.06)\end{array}$ & $\begin{array}{l}.03 \\
(.06)\end{array}$ & $\begin{array}{l}.07 \\
(.51)\end{array}$ \\
\hline Proportion hholds in top decile & $(.07)^{* * *}$ & $(.07)^{* * *}$ & $(.07)^{* * *}$ & $\frac{.26}{(.07)^{* * *}}$ & $(.07)^{* * *}$ & $\begin{array}{c}0.27 \\
(.07)^{* * *}\end{array}$ & $\begin{array}{l}.10 \\
(.5)\end{array}$ \\
\hline Gini coefficient & $(.08)^{* * *}$ & $(.08)^{* * *}$ & $(.08)^{* * *}$ & $\begin{array}{c}.35 \\
(.08)^{* * *}\end{array}$ & $\begin{array}{c}.26 \\
(.08)^{* * *}\end{array}$ & $\begin{array}{c}0.30 \\
(.09)^{* * *}\end{array}$ & $\frac{.34}{(.13)^{* * *}}$ \\
\hline Average per capita expenditure & $\begin{array}{l}-.07 \\
(.07)\end{array}$ & $\begin{array}{l}-.06 \\
(.07)\end{array}$ & $\begin{array}{l}-.01 \\
(.07)\end{array}$ & $\begin{array}{l}-.01 \\
(.07)\end{array}$ & $\begin{array}{l}-.07 \\
(.07)\end{array}$ & $\begin{array}{l}-.07 \\
(.08)\end{array}$ & $\begin{array}{l}-.23 \\
(.28)\end{array}$ \\
\hline Village population & $(.001)^{-.005 * *}$ & $(.001)^{-.005 * *}$ & $(.001)^{* * *}$ & $(. .001)^{* * *}$ & $(0.001)^{-0.006 *}$ & $(0.001)^{* * *}$ & $(.002)^{-.01 * *}$ \\
\hline Male share & $(.16)^{* *}$ & $(.17)^{* *}$ & $(.16)^{-.4 *}$ & $(.16)^{-.41}$ & $(.16)^{* *}$ & $\begin{array}{l}-.18 \\
(.19)\end{array}$ & $\begin{array}{l}.05 \\
(.15)\end{array}$ \\
\hline Farm households & $\begin{array}{l}.04 \\
(.03)\end{array}$ & $\begin{array}{l}.03 \\
(.03)\end{array}$ & $(.03)^{* * *}$ & $\begin{array}{c}.09 \\
(.03)^{* * *}\end{array}$ & $(.05) *$ & $\begin{array}{l}.04 \\
(.03)\end{array}$ & $(.002)^{-.01}$ \\
\hline Farm laborers & $\begin{array}{l}-.03 \\
(.06)\end{array}$ & $\begin{array}{l}-.03 \\
(.06)\end{array}$ & $(.05)^{* * *}$ & $(.05)^{* * *}$ & $\begin{array}{l}-.04 \\
(.06)\end{array}$ & $\begin{array}{l}-.06 \\
(.06)\end{array}$ & \\
\hline Poor letter & $\begin{array}{l}-.05 \\
(.04)\end{array}$ & $\begin{array}{l}-.05 \\
(.04)\end{array}$ & $\begin{array}{l}.02 \\
(.04)\end{array}$ & $\begin{array}{l}.02 \\
(.04)\end{array}$ & $\begin{array}{l}-.06 \\
(.04)\end{array}$ & $\begin{array}{l}-.04 \\
(.05)\end{array}$ & $\begin{array}{l}.01 \\
(.04)\end{array}$ \\
\hline Hours to city & $(.008)^{* * *}$ & $(.008)^{* * *}$ & $(.007)^{* * *}$ & $(.007)^{* * *}$ & $(.01)^{* * *}$ & $\begin{array}{c}0.03 \\
(.01)^{* * *}\end{array}$ & $\begin{array}{l}0.03 \\
(.02)^{*}\end{array}$ \\
\hline One ethnic group & $(.01)^{-.07 * *}$ & $(.01)^{-.07 * *}$ & $(.01)^{-.1}$ & $(.01)^{-.1}$ & $(.01)^{-.07 * *}$ & $(.02)^{-.08 * *}$ & \\
\hline Security post & $(.02)^{* * *}$ & $(.02)^{-.07 * *}$ & & & & & \\
\hline Civilian defense & $(.02)^{*}$ & $(.02)^{*}$ & & & & & \\
\hline Police post & $(.01)^{* * *}$ & $(.01)^{* * *}$ & & & & & \\
\hline Electric Lights & & $(.02)^{* *}$ & & & & & \\
\hline Cook with fuel & & $\begin{array}{l}-.02 \\
(.02)\end{array}$ & & & & & \\
\hline Transport share & & $(.22)$ & & & & & \\
\hline Fuel share & & $(.12)^{*}$ & & & & & \\
\hline Constant & $\begin{array}{l}.14 \\
(.16)\end{array}$ & $\begin{array}{l}.19 \\
(.17)\end{array}$ & $(.09)^{* * *}$ & $(.09)^{-26 * *}$ & $(.21)^{*}$ & 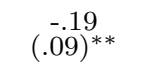 & $\begin{array}{l}-.18 \\
(.51)\end{array}$ \\
\hline Fixed Effects: & District & District & No & No & District & District & District \\
\hline R-squared & .12 & .12 & .03 & .03 & .01 & .02 & .02 \\
\hline $\mathrm{N}$ & 14815 & 14765 & 14815 & 14815 & 14815 & 12208 & 6754 \\
\hline
\end{tabular}

Notes: We report results from OLS regressions where the dependent variable is an indicator of the change in crime from 2005 to 2006 (columns 1-6) and the change in crime from 1998 to 1999 (column 7). Standard errors are shown in parentheses. ***indicates significance at $1 \%$ level, ${ }^{* *}$ at $5 \%$ level, ${ }^{*}$ at $10 \%$ level. 
Table 8: Village Administration Robustness Tests

\begin{tabular}{|c|c|c|c|c|}
\hline & $(1)$ & $(2)$ & $(3)$ & $(4)$ \\
\hline Dependent Variable: & BLT present & Leakage & Undercoverage & $\Delta$ crime $_{v t}$ \\
\hline BLT present & & & & $\begin{array}{c}.04 \\
(.02)^{* *}\end{array}$ \\
\hline Leakage & & & & $\begin{array}{c}.08 \\
(.03)^{* * *}\end{array}$ \\
\hline Undercoverage & & & & $\begin{array}{c}.03 \\
(.02)\end{array}$ \\
\hline$\%$ Households eligible & $\begin{array}{c}.03 \\
(.01)^{* *}\end{array}$ & $\begin{array}{c}-.13 \\
(.009)^{* * *}\end{array}$ & $\begin{array}{c}.24 \\
(.01)^{* * *}\end{array}$ & $\begin{array}{l}-.06 \\
(.03)^{* *}\end{array}$ \\
\hline Rural & $\begin{array}{l}.004 \\
(.009)\end{array}$ & $\begin{array}{l}.007 \\
(.006)\end{array}$ & $\begin{array}{l}-.002 \\
(.009)\end{array}$ & $\begin{array}{l}.03 \\
(.02)\end{array}$ \\
\hline Proportion hholds in 2nd top decile & $\begin{array}{l}-.16 \\
(.03)^{* * *}\end{array}$ & $\begin{array}{l}-.17 \\
(.02)^{* * *}\end{array}$ & $\begin{array}{c}-.46 \\
(.03)^{* * *}\end{array}$ & $\begin{array}{l}.05 \\
(.06)\end{array}$ \\
\hline Proportion hholds in top decile & $\begin{array}{c}-.44 \\
(.03)^{* * *}\end{array}$ & $\begin{array}{c}-.17 \\
(.02)^{* * *}\end{array}$ & $\begin{array}{c}-.36 \\
(.03)^{* * *}\end{array}$ & $\begin{array}{c}.22 \\
(.07)^{* * *}\end{array}$ \\
\hline Gini coefficient & $\begin{array}{c}.61 \\
(.04)^{* * *}\end{array}$ & $\begin{array}{c}-.003 \\
(.03)\end{array}$ & $\begin{array}{c}.32 \\
(.04)^{* * *}\end{array}$ & $\begin{array}{c}.27 \\
(.08)^{* * *}\end{array}$ \\
\hline Average per capita expenditure & $\begin{array}{c}-.16 \\
(.03)^{* * *}\end{array}$ & $\begin{array}{l}-.04 \\
(.02)^{*}\end{array}$ & $\begin{array}{l}-.05 \\
(.04)\end{array}$ & $\begin{array}{l}-.06 \\
(.07)\end{array}$ \\
\hline Village population & $\begin{array}{c}-.001 \\
(.0006)^{* *}\end{array}$ & $\begin{array}{c}-.003 \\
(.0004)^{* * *}\end{array}$ & $\begin{array}{c}.004 \\
(.0007)^{* * *}\end{array}$ & $\begin{array}{l}-.006 \\
(.001)^{* * *}\end{array}$ \\
\hline Male share & $\begin{array}{l}-.04 \\
(.08)\end{array}$ & $\begin{array}{l}-.06 \\
(.05)\end{array}$ & $\begin{array}{l}.07 \\
(.08)\end{array}$ & $\begin{array}{l}-.33 \\
(.17)^{* *}\end{array}$ \\
\hline Farm households & $\begin{array}{c}.04 \\
(.01)^{* *}\end{array}$ & $\begin{array}{c}.08 \\
(.01)^{* * *}\end{array}$ & $\begin{array}{l}-.03 \\
(.01)^{* *}\end{array}$ & $\begin{array}{c}.05 \\
(.03)^{*}\end{array}$ \\
\hline Farm laborers & $\begin{array}{l}-.01 \\
(.03)\end{array}$ & $\begin{array}{l}.02 \\
(.02)\end{array}$ & $\begin{array}{l}-.04 \\
(.03)\end{array}$ & $\begin{array}{l}-.03 \\
(.06)\end{array}$ \\
\hline Poor letter & $\begin{array}{l}.04 \\
(.02)^{*}\end{array}$ & $\begin{array}{c}.06 \\
(.01)^{* * *}\end{array}$ & $\begin{array}{c}-.003 \\
(.02)\end{array}$ & $\begin{array}{l}-.06 \\
(.04)\end{array}$ \\
\hline Hours to city & $\begin{array}{l}.005 \\
(.004)\end{array}$ & $\begin{array}{c}.02 \\
(.003)^{* * *}\end{array}$ & $\begin{array}{c}-.01 \\
(.004)^{* * *}\end{array}$ & $\begin{array}{c}.03 \\
(.008)^{* * *}\end{array}$ \\
\hline One ethnic group & $\begin{array}{l}.002 \\
(.006)\end{array}$ & $\begin{array}{c}-.02 \\
(.004)^{* * *}\end{array}$ & $\begin{array}{l}.002 \\
(.007)\end{array}$ & $\begin{array}{l}-.07 \\
(.01)^{* * *}\end{array}$ \\
\hline Village has a head & $\begin{array}{l}.003 \\
(.04)\end{array}$ & $\begin{array}{c}.06 \\
(.03)^{* *}\end{array}$ & $\begin{array}{l}-.05 \\
(.04)\end{array}$ & $\begin{array}{l}-.04 \\
(.08)\end{array}$ \\
\hline Head's age & $\begin{array}{l}-.0002 \\
(.0003)\end{array}$ & $\begin{array}{l}-.0003 \\
(.0002)\end{array}$ & $\begin{array}{l}.0001 \\
(.0003)\end{array}$ & $\begin{array}{l}.001 \\
(.0007)\end{array}$ \\
\hline Head male & $\begin{array}{c}-.001 \\
(.01)\end{array}$ & $\begin{array}{l}.01 \\
(.01)\end{array}$ & $\begin{array}{l}-.01 \\
(.02)\end{array}$ & $\begin{array}{c}-.005 \\
(.03)\end{array}$ \\
\hline Head finished primary or secondary school & $\begin{array}{l}-.03 \\
(.02)\end{array}$ & $\begin{array}{l}-.02 \\
(.02)\end{array}$ & $\begin{array}{l}.04 \\
(.02)\end{array}$ & $\begin{array}{l}-.01 \\
(.05)\end{array}$ \\
\hline Head tertiary educated & $\begin{array}{l}-.03 \\
(.02)\end{array}$ & $\begin{array}{l}-.03 \\
(.02)\end{array}$ & $\begin{array}{l}.05 \\
(.03)^{*}\end{array}$ & $\begin{array}{c}-.009 \\
(.05)\end{array}$ \\
\hline Village has a secretary & $\begin{array}{l}.06 \\
(.04)^{*}\end{array}$ & $\begin{array}{c}.06 \\
(.02)^{* *}\end{array}$ & $\begin{array}{l}-.06 \\
(.04)\end{array}$ & $\begin{array}{l}.02 \\
(.07)\end{array}$ \\
\hline Secretary's age & $\begin{array}{l}-.0007 \\
(.0003)^{* *}\end{array}$ & $\begin{array}{l}-.0005 \\
(.0002)^{* *}\end{array}$ & $\begin{array}{c}.0008 \\
(.0003)^{* *}\end{array}$ & $\begin{array}{c}.001 \\
(.0006)^{* *}\end{array}$ \\
\hline Secretary male & $\begin{array}{l}.01 \\
(.01)\end{array}$ & $\begin{array}{l}.006 \\
(.007)\end{array}$ & $\begin{array}{l}-.02 \\
(.01)\end{array}$ & $\begin{array}{l}-.03 \\
(.02)\end{array}$ \\
\hline Secretary finished primary or secondary school & $\begin{array}{l}-.03 \\
(.03)\end{array}$ & $\begin{array}{l}-.04 \\
(.02)^{*}\end{array}$ & $\begin{array}{l}.03 \\
(.03)\end{array}$ & $\begin{array}{l}-.07 \\
(.06)\end{array}$ \\
\hline Secretary tertiary educated & $\begin{array}{l}-.04 \\
(.03)\end{array}$ & $\begin{array}{l}-.04 \\
(.02)^{*}\end{array}$ & $\begin{array}{l}.05 \\
(.03)^{*}\end{array}$ & $\begin{array}{l}-.11 \\
(.06)^{*}\end{array}$ \\
\hline Village has a BPD & $\begin{array}{c}-.005 \\
(.04)\end{array}$ & $\begin{array}{l}.01 \\
(.03)\end{array}$ & $\begin{array}{c}-.008 \\
(.04)\end{array}$ & $\begin{array}{l}.09 \\
(.08)\end{array}$ \\
\hline BPD Head's age & $\begin{array}{l}.0002 \\
(.0003)\end{array}$ & $\begin{array}{l}-.0002 \\
(.0002)\end{array}$ & $\begin{array}{l}.0003 \\
(.0003)\end{array}$ & $\begin{array}{l}-.0005 \\
(.0007)\end{array}$ \\
\hline
\end{tabular}

(continued over page) 
Table 8 (continued)

BPD Head male

BPD Head finished primary or secondary school

BPD Head tertiary educated

Village has LPMD

LPMD Head's age

LPMD Head finished primary or secondary school

LPMD Head tertiary educated

Constant
LPMD Head male
(1)

(2)

\begin{tabular}{cccc}
-.03 & -.02 & .04 & .006 \\
$(.03)$ & $(.02)$ & $(.03)$ & $(.06)$ \\
.03 & .02 & -.04 & -.06 \\
$(.02)$ & $(.02)$ & $(.02)$ & $(.05)$ \\
.03 & .02 & -.04 & -.12 \\
$(.02)$ & $(.02)$ & $(.03)$ & $(.05)^{* *}$ \\
-.0004 & .04 & -.07 & -.11 \\
$(.05)$ & $(.03)$ & $(.05)$ & $(.1)$ \\
.0001 & -.0003 & .0005 & .001 \\
$(.0003)$ & $(.0002)$ & $(.0003)$ & $(.0007)^{*}$ \\
-.04 & .005 & .02 & .11 \\
$(.04)$ & $(.03)$ & $(.04)$ & $(.08)$ \\
.03 & -.02 & .01 & -.03 \\
$(.02)^{*}$ & $(.01)$ & $(.02)$ & $(.04)$ \\
.03 & -.02 & .02 & -.02 \\
$(.02)$ & $(.01)$ & $(.02)$ & $(.04)$ \\
.88 & .67 & .05 & .01 \\
$(.08)^{* * *}$ & $(.06)^{* * *}$ & $(.09)$ & $(.17)$ \\
\hline & & & \\
District & District & District & District \\
.24 & .32 & .25 & .12 \\
14815 & 14815 & 14815 & 14815 \\
\hline
\end{tabular}
14815

(4) 006 .06 $.05)$ .12 11 $.1)$ $007)^{*}$ (11) .03 $(.04)$ $(.04)$ .01

\begin{tabular}{lcccc} 
Fixed effects: & District & District & District & District \\
R-squared & .24 & .32 & .25 & .12 \\
$\mathrm{~N}$ & 14815 & 14815 & 14815 & 14815 \\
\hline
\end{tabular}

Notes: We report results from OLS regressions. Standard errors are shown in parentheses. ${ }^{* * *}$ indicates significance at $1 \%$ level, ${ }^{* *}$ at $5 \%$ level, ${ }^{*}$ at $10 \%$ level. 
Table 9: Instrumental Variables Robustness Tests

\begin{tabular}{|c|c|c|c|c|c|}
\hline & $(1)$ & $(2)$ & $(3)$ & $(4)$ & $(5)$ \\
\hline Dependent variables: & Leakage & Undercoverage & $\overline{\Delta c r i m e}_{v t}$ & $\Delta$ crime $_{v t}$ & $\Delta$ crime $_{v t}$ \\
\hline Leakage BPS & $\begin{array}{c}.16 \\
(.007)^{* * *}\end{array}$ & $\frac{1}{(.01)^{* * *}}$ & & & \\
\hline Undercoverage BPS & $\begin{array}{c}.03 \\
(.005)^{* * *}\end{array}$ & $\begin{array}{c}.27 \\
(.008)^{* * *}\end{array}$ & & & \\
\hline BLT present & $\begin{array}{c}.18 \\
(.006)^{* * *}\end{array}$ & $\begin{array}{c}-.25 \\
(.008)^{* * *}\end{array}$ & $\begin{array}{l}.006 \\
(.04)\end{array}$ & $\begin{array}{l}-.02 \\
(.04)\end{array}$ & $\begin{array}{l}-.05 \\
(.04)\end{array}$ \\
\hline Leakage & & & $\begin{array}{l}.26 \\
(.15)^{*}\end{array}$ & $\begin{array}{c}.36 \\
(.13)^{* * *}\end{array}$ & $\begin{array}{c}.43 \\
(.12)^{* * *}\end{array}$ \\
\hline Undercoverage & & & $\begin{array}{c}.05 \\
(.07)\end{array}$ & $\begin{array}{l}.004 \\
(.06)\end{array}$ & $\begin{array}{c}-.006 \\
(.06)\end{array}$ \\
\hline$\%$ Households eligible & $\begin{array}{c}-.13 \\
(.009)^{* * *}\end{array}$ & $\begin{array}{c}.25 \\
(.01)^{* * *}\end{array}$ & $\begin{array}{l}-.04 \\
(.04)\end{array}$ & $\begin{array}{l}-.05 \\
(.03)\end{array}$ & $\begin{array}{l}.006 \\
(.03)\end{array}$ \\
\hline Rural & $\begin{array}{l}.004 \\
(.006)\end{array}$ & $\begin{array}{c}-.0000697 \\
(.009)\end{array}$ & $\begin{array}{l}.03 \\
(.02)\end{array}$ & $\begin{array}{l}.03 \\
(.02)^{*}\end{array}$ & $\begin{array}{l}.03 \\
(.02)\end{array}$ \\
\hline Proportion hholds in 2nd top decile & $\begin{array}{c}-.11 \\
(.02)^{* * *}\end{array}$ & $\begin{array}{c}-.36 \\
(.03)^{* * *}\end{array}$ & $\begin{array}{l}.09 \\
(.07)\end{array}$ & $\begin{array}{l}.07 \\
(.07)\end{array}$ & $\begin{array}{l}.06 \\
(.07)\end{array}$ \\
\hline Proportion hholds in top decile & $\begin{array}{l}-.07 \\
(.02)^{* * *}\end{array}$ & $\begin{array}{c}-.37 \\
(.03)^{* * *}\end{array}$ & $\begin{array}{c}.25 \\
(.07)^{* * *}\end{array}$ & $\begin{array}{c}.21 \\
(.07)^{* * *}\end{array}$ & $\begin{array}{c}.23 \\
(.08)^{* * *}\end{array}$ \\
\hline Gini coefficient & $\begin{array}{l}-.14 \\
(.03)^{* * *}\end{array}$ & $\begin{array}{c}.41 \\
(.04)^{* * *}\end{array}$ & $\begin{array}{c}.27 \\
(.09)^{* * *}\end{array}$ & $\begin{array}{c}.38 \\
(.09)^{* * *}\end{array}$ & $\begin{array}{c}.41 \\
(.09)^{* * *}\end{array}$ \\
\hline Average per capita expenditure & $\begin{array}{l}-.01 \\
(.02)\end{array}$ & $\begin{array}{l}-.08 \\
(.03)^{* *}\end{array}$ & $\begin{array}{l}-.07 \\
(.07)\end{array}$ & $\begin{array}{l}-.04 \\
(.07)\end{array}$ & $\begin{array}{l}-.01 \\
(.07)\end{array}$ \\
\hline Village population & $\begin{array}{c}-.002 \\
(.0004)^{* * *}\end{array}$ & $\begin{array}{c}.003 \\
(.0006)^{* * *}\end{array}$ & $\begin{array}{c}-.006 \\
(.001)^{* * *}\end{array}$ & $\begin{array}{l}-.007 \\
(.001)^{* * *}\end{array}$ & $\begin{array}{l}-.007 \\
(.001)^{* * *}\end{array}$ \\
\hline Male share & $\begin{array}{l}-.03 \\
(.05)\end{array}$ & $\begin{array}{l}.06 \\
(.08)\end{array}$ & $\begin{array}{l}-.33 \\
(.17)^{* *}\end{array}$ & $\begin{array}{l}-.37 \\
(.16)^{* *}\end{array}$ & $\begin{array}{c}-.45 \\
(.16)^{* * *}\end{array}$ \\
\hline Farm households & $\begin{array}{c}.06 \\
(.009)^{* * *}\end{array}$ & $\begin{array}{l}-.02 \\
(.01)\end{array}$ & $\begin{array}{l}.04 \\
(.03)\end{array}$ & $\begin{array}{l}.04 \\
(.03)\end{array}$ & $\begin{array}{c}.07 \\
(.03)^{* *}\end{array}$ \\
\hline Farm laborers & $\begin{array}{l}.02 \\
(.02)\end{array}$ & $\begin{array}{l}-.03 \\
(.03)\end{array}$ & $\begin{array}{l}-.04 \\
(.06)\end{array}$ & $\begin{array}{c}-.18 \\
(.05)^{* * *}\end{array}$ & $\begin{array}{c}-.28 \\
(.05)^{* * *}\end{array}$ \\
\hline Poor letter & $\begin{array}{c}.05 \\
(.01)^{* * *}\end{array}$ & $\begin{array}{l}-.005 \\
(.02)\end{array}$ & $\begin{array}{l}-.07 \\
(.04)\end{array}$ & $\begin{array}{l}-.04 \\
(.04)\end{array}$ & $\begin{array}{l}-.02 \\
(.04)\end{array}$ \\
\hline Hours to city & $(.002)^{* * *}$ & $\begin{array}{c}-.01 \\
(.004)^{* * *}\end{array}$ & $\begin{array}{c}.03 \\
(.008)^{* * *}\end{array}$ & $\begin{array}{c}.03 \\
(.008)^{* * *}\end{array}$ & $\begin{array}{c}.03 \\
(.008)^{* * *}\end{array}$ \\
\hline One ethnic group & $\begin{array}{c}-.02 \\
(.004)^{* * *}\end{array}$ & $\begin{array}{l}.003 \\
(.006)\end{array}$ & $\begin{array}{l}-.07 \\
(.01)^{* * *}\end{array}$ & $\begin{array}{c}-.1 \\
(.01)^{* * *}\end{array}$ & $\begin{array}{c}-.09 \\
(.01)^{* * *}\end{array}$ \\
\hline Constant & $\begin{array}{c}.06 \\
(.03)^{* *}\end{array}$ & $\begin{array}{c}.35 \\
(.04)^{* * *}\end{array}$ & $\begin{array}{l}-.21 \\
(.1)^{* *}\end{array}$ & $\begin{array}{l}-.16 \\
(.1)^{*}\end{array}$ & $\begin{array}{l}-.16 \\
(.09)^{*}\end{array}$ \\
\hline Fixed Effects: & District & District & District & Province & No \\
\hline $\begin{array}{l}\text { F-test of instruments: } \\
\text { (p-value) }\end{array}$ & $\begin{array}{c}255.4 \\
(0.000)\end{array}$ & $\begin{array}{c}509.1 \\
(0.000)\end{array}$ & & & \\
\hline R-squared & .19 & .24 & .02 & .02 & .02 \\
\hline $\mathrm{N}$ & 14815 & 14815 & 14815 & 14815 & 14815 \\
\hline
\end{tabular}

Notes: We report first and second stage results from instrumental variable estimation. Standard errors are shown in parentheses. ${ }^{* * *}$ indicates significance at $1 \%$ level, ${ }^{* *}$ at $5 \%$ level, ${ }^{*}$ at $10 \%$ level. 
Table 10: IFLS Social Capital Results

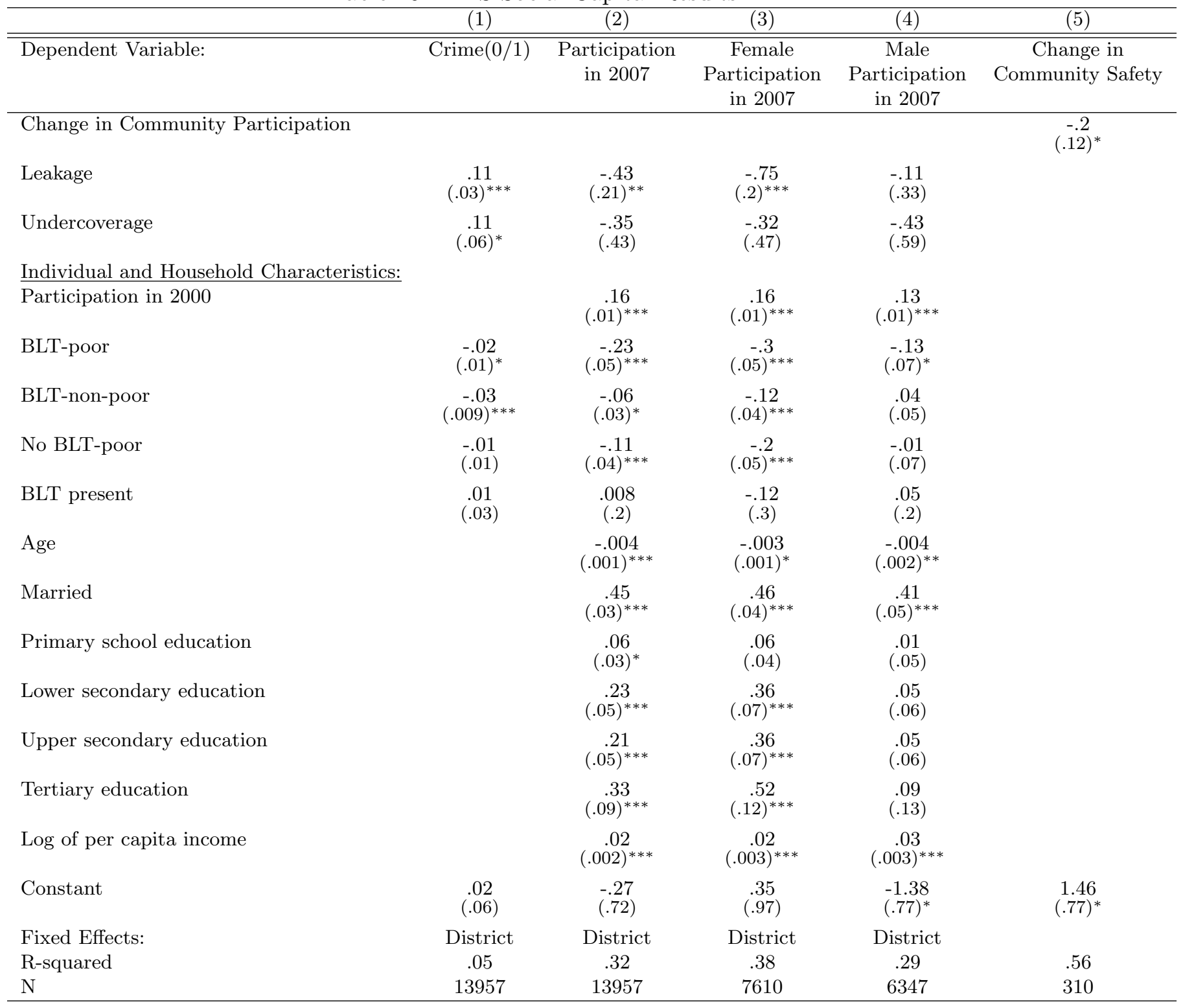

Notes: We report results from OLS regressions. Standard errors are shown in parentheses and are clustered in columns (1)-(4). ***indicates significance at $1 \%$ level, ${ }^{* *}$ at $5 \%$ level, $*$ at $10 \%$ level. Controls were also included for the share of eligible households in the village; whether the household was in the top or second top decile of the national income distribution; the percentage of village households in each of these deciles; the gini coefficient of per capita income in the village; distance from the city in minutes and the village population. 
Figure 1: Timing of Program and Surveys

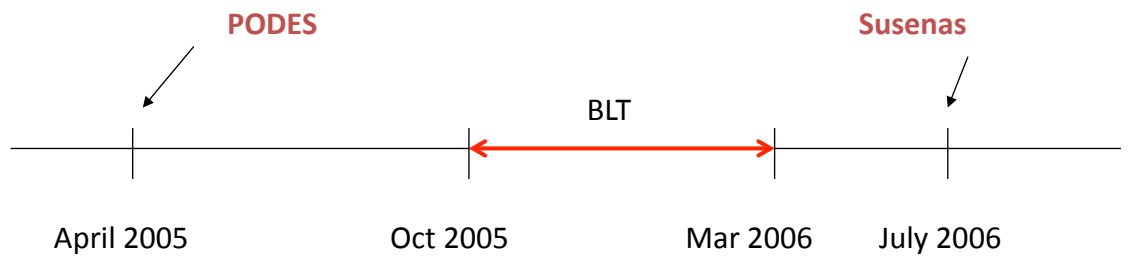


Figure 2: Kernel Density Estimate of Village Leakage Rates

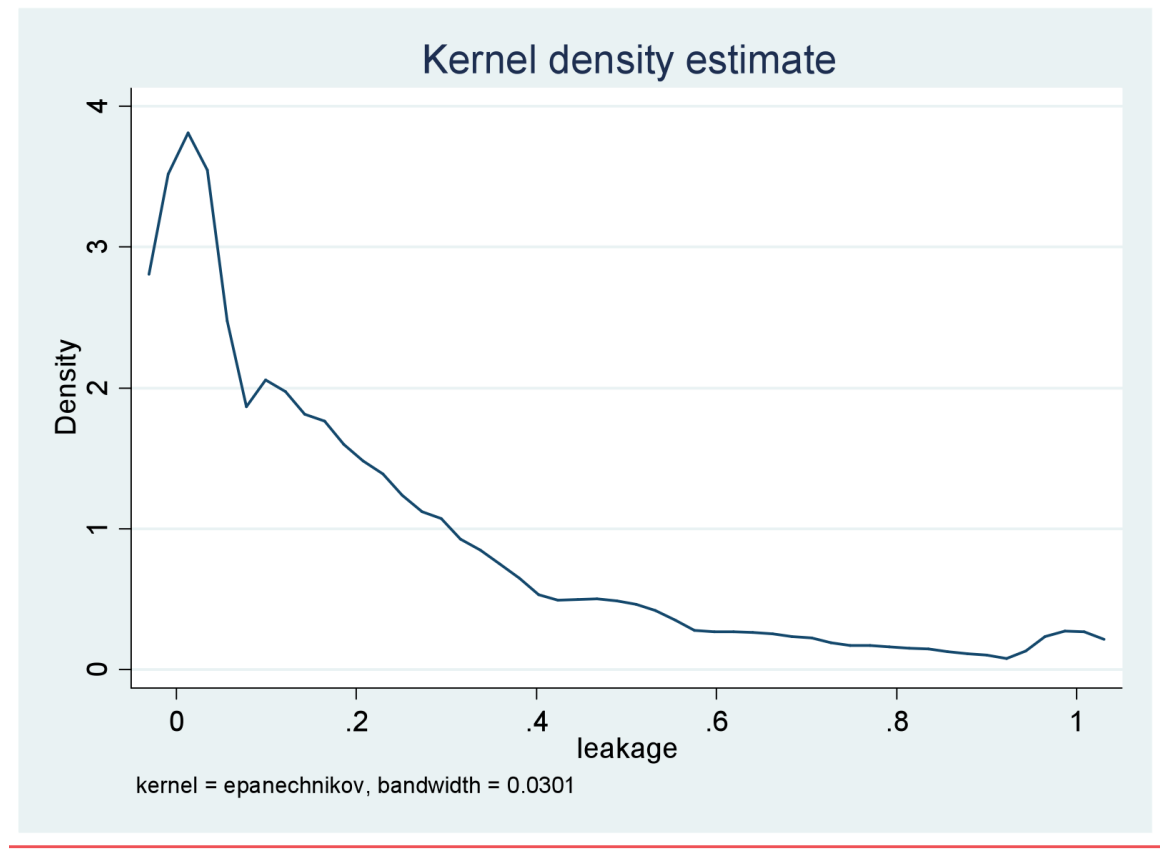


Figure 3: Kernel Density Estimate of Village Undercoverage Rates

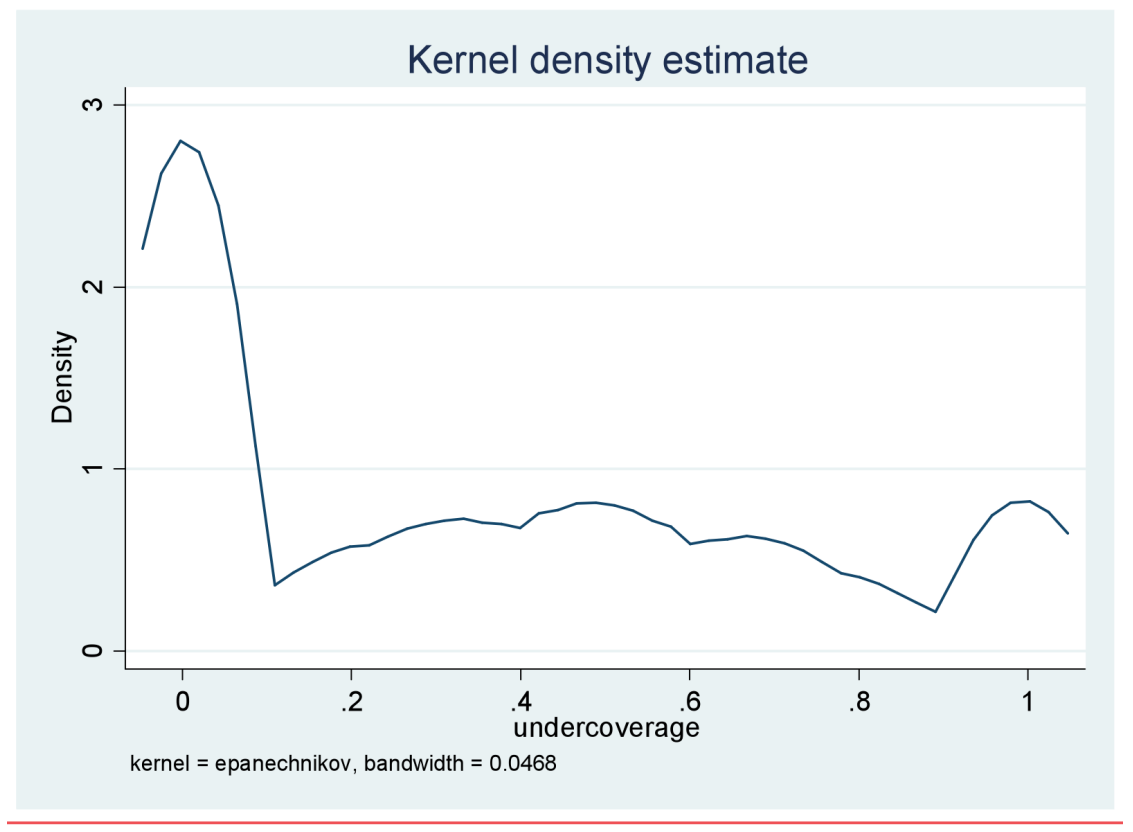


Figure 4: Comparison of Trends in Crime Rates (Share of Villages Experiencing Crime)
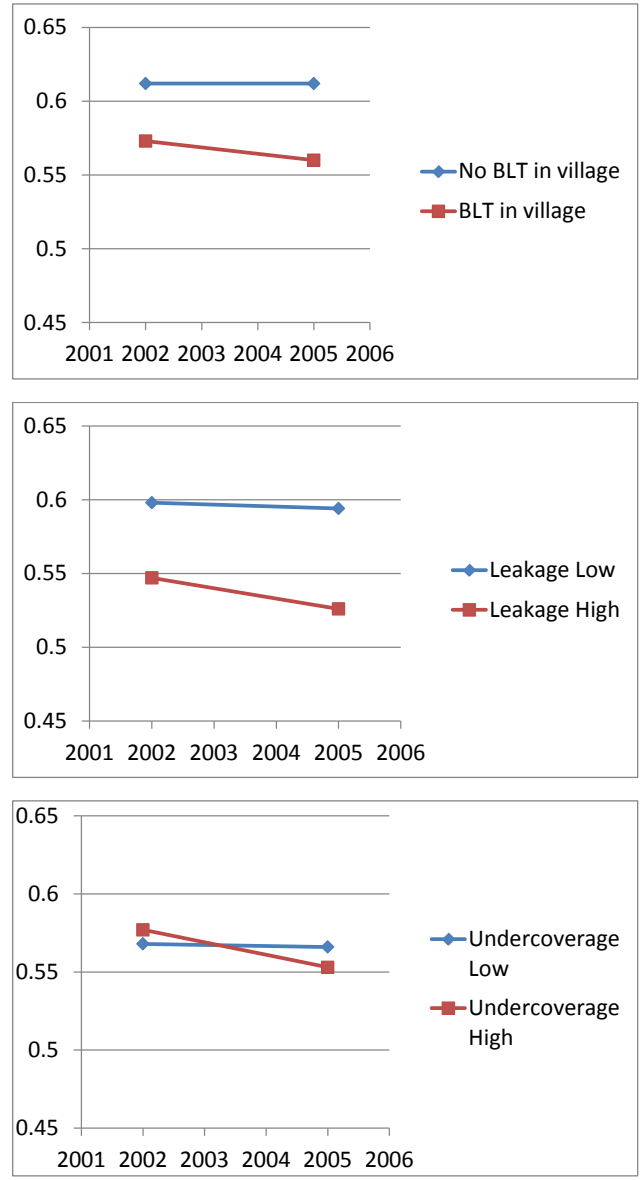

Source: PODES 2005 and PODES 2002. 
Appendix 
Table 11: Questions in PSE05 Questionnaire

1. Number of household members

2. Floor area

3. Broadest floor area type

4. Broadest wall area type

5. Toilet Facilities

6. Source of Drinking Water

7. Main Source of Lighting

8. Type of Cooking Fuel

9. Frequency of meat/chicken/milk purchases per week

10. Meal frequency per day

11. Frequency of new clothes purchases

12. Access to treatment at a puskesmas or clinic for sick householders

13. Main field of work of household head

14. Highest level of education of household head

15. Minimum assets of Rp500,000 (Yes/No):
a. Savings
b. Gold
c. Color TV
d. Livestock
e. Motor cycle 


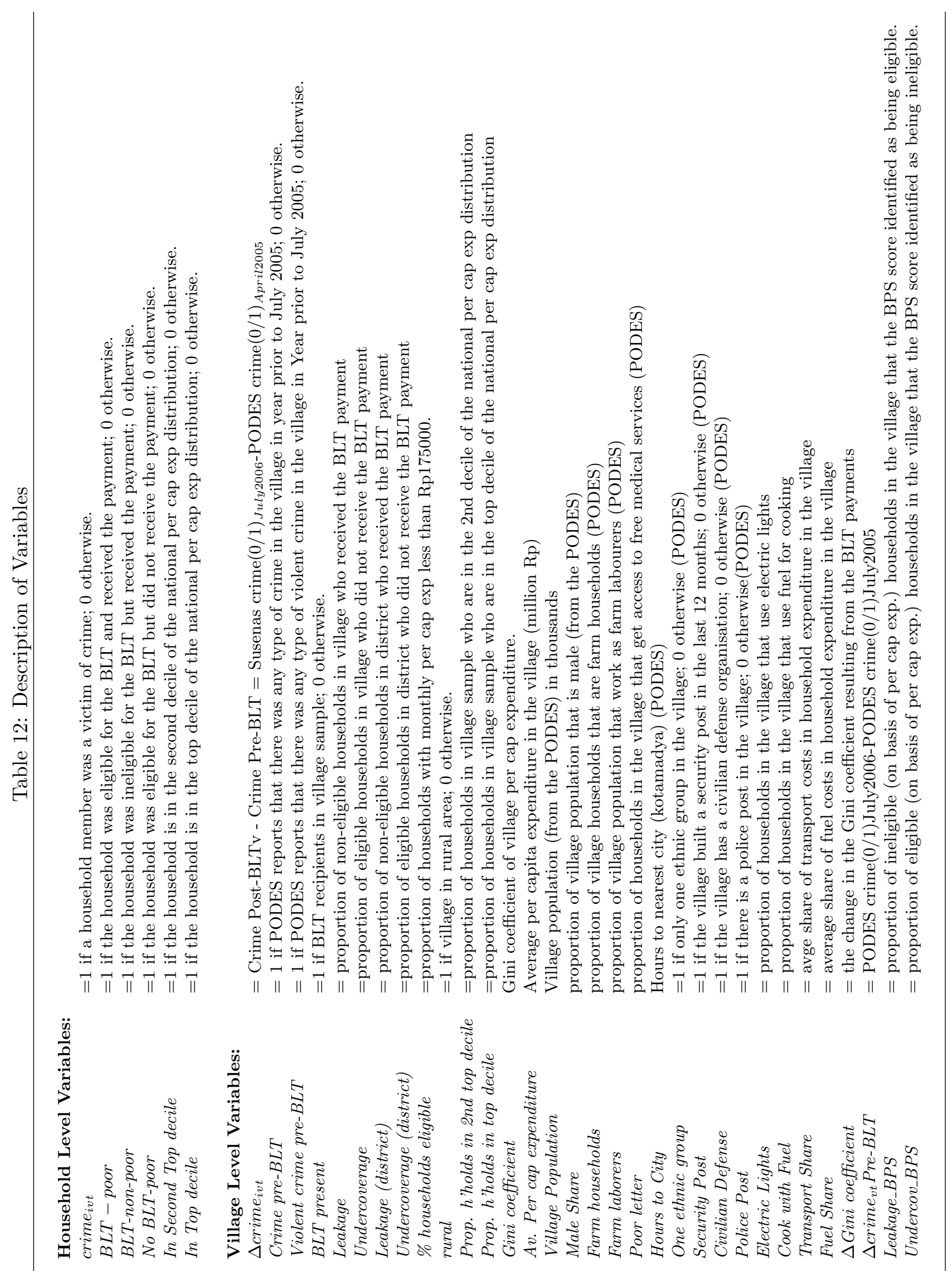


Table 13: Ordered Logit Results (Analogous to Table 6, Column 3)

\begin{tabular}{|c|c|}
\hline Dependent Variable: & $\Delta$ crime $_{v t}$ \\
\hline BLT present & $\begin{array}{c}.13 \\
(.06)^{* *}\end{array}$ \\
\hline Leakage & $\begin{array}{c}.26 \\
(.09)^{* * *}\end{array}$ \\
\hline Undercoverage & $\begin{array}{l}.09 \\
(.06)^{*}\end{array}$ \\
\hline Eligible Households & $\begin{array}{c}-.2 \\
(.09)^{* *}\end{array}$ \\
\hline Rural & $\begin{array}{l}.11 \\
(.06)^{*}\end{array}$ \\
\hline Proportion of households in second top decile & $\begin{array}{l}.11 \\
(.2)\end{array}$ \\
\hline Proportion of households in top decile & $\begin{array}{c}.79 \\
(.22)^{* * *}\end{array}$ \\
\hline Gini coefficient & $\frac{.8}{(.26)^{* * *}}$ \\
\hline Average per capita expenditure & $\begin{array}{l}-.23 \\
(.24)\end{array}$ \\
\hline Village Population & $\begin{array}{c}-.02 \\
(.004)^{* * *}\end{array}$ \\
\hline Male Share & $\begin{array}{l}-1.09 \\
(.53)^{* *}\end{array}$ \\
\hline Farm households & $\begin{array}{l}.14 \\
(.09)\end{array}$ \\
\hline Farm laborers & $\begin{array}{l}-.13 \\
(.19)\end{array}$ \\
\hline Poor letter & $\begin{array}{l}-.19 \\
(.14)\end{array}$ \\
\hline Hours to city & $\frac{.11}{(.02)^{* * *}}$ \\
\hline One ethnicity & $\begin{array}{c}-.25 \\
(.04)^{* * *}\end{array}$ \\
\hline Fixed Effects & District \\
\hline Pseudo-R-squared & 0.064 \\
\hline $\mathrm{N}$ & 14815 \\
\hline
\end{tabular}

Notes: The dependent variable is an indicator of the change in crime from 2005 to 2006 where 1 indicates that crime has increased; 0 indicates no change; -1 indicates that crime has decreased. Standard errors are clustered at the village level and are shown in parentheses. ***indicates significance at $1 \%$ level, ${ }^{* *}$ at $5 \%$ level, ${ }^{*}$ at $10 \%$ level. 